\title{
Ancient tin production: Slags from the Iron Age Carvalhelhos hillfort (NW Iberian Peninsula)
}

\author{
Elin Figueiredo ${ }^{\mathrm{a},{ }^{*}, \text { João Fonte }}{ }^{\mathrm{b}, 1}$, Alexandre Lima ${ }^{\mathrm{c}}$, João Pedro Veiga ${ }^{\mathrm{a}}$, Rui J.C. Silva ${ }^{\mathrm{a}}$, \\ José Mirão ${ }^{\mathrm{d}}$ \\ a Centro de Investigação de Materiais, Instituto de Nanoestruturas, Nanomodelação e Nanofabricação (CENIMAT/i3N), Faculdade de Ciências e Tecnologia, \\ Universidade NOVA de Lisboa, 2829-516 Caparica, Portugal \\ ${ }^{\mathrm{b}}$ Institute of Heritage Sciences, Spanish National Research Council (Incipit/CSIC), 15705 Santiago de Compostela, Spain \\ ${ }^{\mathrm{c}}$ Instituto de Ciências da Terra (ICT, Pólo da UP), Departamento de Geociências, Ambiente e Ordenamento do Território, Faculdade de Ciências, Universidade \\ do Porto, 4169-007 Porto, Portugal \\ d Laboratório Hercules, Universidade de Évora, Apartado 94, 700-809 Évora, Portugal
}

\section{A R T I C L E I N F O}

\section{Article history:}

Received 3 April 2015

Received in revised form

20 January 2018

Accepted 9 February 2018

Available online 5 March 2018

\section{Keywords:}

Archaeometallurgy

Smelting

Slags

Tin

Iberian Peninsula

Iron Age

Roman transition

\begin{abstract}
A B S T R A C T
Provenance and production of tin in the Ancient World has since long been a major topic of discussion among archaeologists. In Western Europe, where significant tin ore (cassiterite) deposits are known, only a few remains of ancient tin production, such as tin slags, have been detected. In the present work, elemental and microstructural analyses by WDXRF, SEM-EDS and XRD were performed on recently recognised tin slags from the Iron Age Carvalhelhos hillfort located in NW Iberia, a territory that represents the largest extension with tin mineralisation in Western Europe. Elemental and microstructural characterisation of cassiterite collected in a pilot field survey in the region of the hillfort are presented and discussed, as well as two ceramic fragments that could be part of a smelting structure and an iron slag from the settlement. Results show that the tin slags have variable but high contents in Sn, similarly to Pre-Medieval tin slags found in other Western European areas, but also high contents of Ta and $\mathrm{Nb}$, which specifically distinguish them from other tin slags, such as those found in SW Britain. Tin ores from the hillfort region frequently have $\mathrm{Ta}$ and $\mathrm{Nb}$ in cassiterite solid solution or as inclusions of columbite group minerals, relating well with the Carvalhelhos tin slags. Up to present, the Carvalhelhos slags are amongst the very few ancient tin slags known in Western Europe, and their study can contribute to a better knowledge on ancient tin sources and trade routes.
\end{abstract}

(c) 2018 Elsevier Ltd. All rights reserved.

\section{Introduction}

Tin (Sn) ores, such as cassiterite, are concentrated in a few geographical areas in Western Europe in contrast with copper $(\mathrm{Cu})$ ores which are more widely spread. Among these regions are SW Britain, W France and NW Iberia, where tin deposits were available for ancient exploitation (Fig. 1a).

Tin was necessary for making bronze ( $\mathrm{Cu}-\mathrm{Sn}$ alloy), and access to it was important from Bronze Age onwards for the production of various types of artefacts. Nevertheless, despite much evidence for copper production and bronze artefact manufacturing, until now

\footnotetext{
* Corresponding author.

E-mail address: esf@fct.unl.pt (E. Figueiredo).

1 Present address: Department of Archaeology, University of Exeter, Laver Building, North Park Road, EX4 4QE, Exeter, UK.
}

only scarce evidence for metallic tin production, such as tin slags or tin smelting furnaces has been found in archaeological PreMedieval contexts (Malham, 2010). The very few tin slags that have been identified (Table 1 ) originate from areas where cassiterite was available, and comprise: seven pieces of slag from Early Bronze Age ( 1600 BCE) ritual enclosure at Caerloggas, Cornwall, SW England; a single tiny bead of slag discovered in one of the roundhouses of the Late Bronze Age settlement at Dean Moor, Devon, SW England (this particular slag is described with some detail but no analyses are available) (Tylecote et al., 1989; Malham, 2010); small size slags found in a geological borehole and dated to the Middle Bronze Age $(\sim 1400-1100$ cal BCE) from St Renan in Bretagne, W France (Mahé-Le Carlier et al., 2001) and Roman tin slags from Centum Cellas, Belmonte, Portugal (Merideth, 1996).

Many of these slags underwent chemical and mineralogical analysis. These analyses showed that ancient tin slags are 

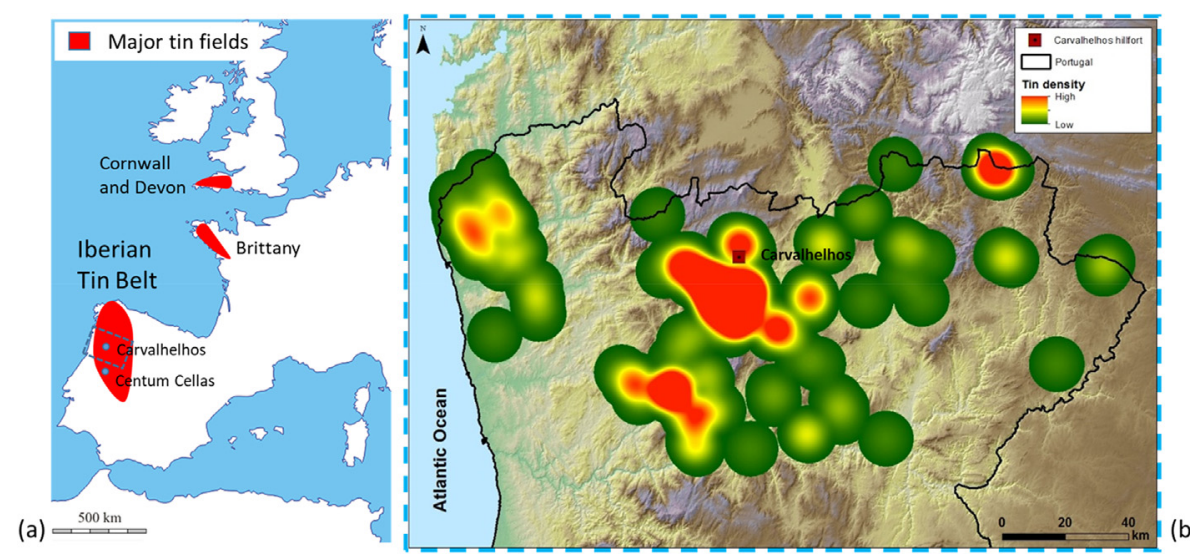

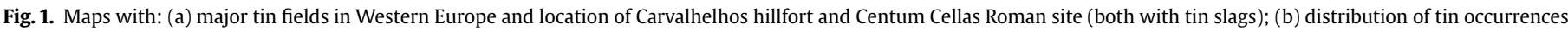

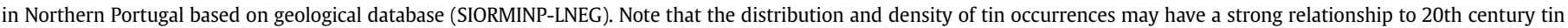
extraction activities.

Table 1

List of ancient (Pre-Medieval) tin slags from Western Europe with some information about physical and chemical characteristics and notes on local/regional ores.

\begin{tabular}{|c|c|c|c|c|c|}
\hline Tin slags & $\begin{array}{l}\text { Chronological } \\
\text { attribution }\end{array}$ & $\begin{array}{l}\text { Size, colour } \\
\text { and texture }\end{array}$ & Finding context & $\begin{array}{l}\text { Elemental, microstructural or other } \\
\text { characteristics }\end{array}$ & $\begin{array}{l}\text { Notes on cassiterite ores from local or regional } \\
\text { areas }\end{array}$ \\
\hline $\begin{array}{l}\text { Centum Cellas, Beira } \\
\text { Baixa, Central } \\
\text { Portugal } \\
\text { (Merideth, 1996) }\end{array}$ & $\begin{array}{l}\text { Roman, } 1-3 \\
\text { century CE }\end{array}$ & $\begin{array}{l}\text { Medium size (1 } \\
-4 \mathrm{~cm}) ; \text { Dark; } \\
\text { Vitreous }\end{array}$ & $\begin{array}{l}\text { Archaeological } \\
\text { excavation of a } \\
\text { Roman context }\end{array}$ & $\begin{array}{l}\text { High } \mathrm{Sn}, \mathrm{Ta}, \mathrm{Nb}, \mathrm{Fe} \text { and Ti values; } 5-17 \% \mathrm{SnO}_{2}, 6 \\
-14 \% \mathrm{Nb}_{2} \mathrm{O}_{5}, 9-12 \% \mathrm{Ta}_{2} \mathrm{O}_{5}, 25-30 \% \mathrm{Fe}_{2} \mathrm{O}_{3} \text { and } \\
8-16 \% \mathrm{TiO}_{2} \text {. Slags under furnace testing shows } \\
\text { to begin to soften at } 1200^{\circ} \mathrm{C} \text { and total fusion at } \\
\sim 1400{ }^{\circ} \mathrm{C} \text {. }\end{array}$ & $\begin{array}{l}\text { Cassiterite ores are present in both primary and } \\
\text { secondary deposits. Associated with } \mathrm{W} \text { or Ta- } \\
\mathrm{Nb} \text {. Cassiterite does frequently show banded } \\
\text { regions rich in elements such as } \mathrm{Nb}, \mathrm{Ta}, \mathrm{Ti} \text { and } \\
\text { Fe. }\end{array}$ \\
\hline $\begin{array}{l}\text { St Renan, Bretagne, W } \\
\text { France (Mahé-Le } \\
\text { Carlier et al., 2001) }\end{array}$ & $\begin{array}{l}\text { Middle } \\
\text { Bronze Age }\end{array}$ & $\begin{array}{l}\text { Small size, } 1 \\
-2 \mathrm{~mm}\end{array}$ & $\begin{array}{l}\text { Geological } \\
\text { borehole }\end{array}$ & $\begin{array}{l}\text { Slags with different compositions and } \\
\text { microstructures. Some still have unaltered } \\
\text { cassiterite grains with associated minerals } \\
\text { (quartz and feldspar) from the primary rock. } \\
\text { Vitreous matrix can show absence of } \mathrm{Sn} \text { or can } \\
\text { be composed by } \mathrm{Sn}, \mathrm{Si}, \mathrm{Al}, \mathrm{Fe} \text { and Ti oxides. } \\
\text { Some show dendrites of } \mathrm{SnO}_{2} \text { and others } \\
\text { metallic Sn prills inside. }\end{array}$ & $\begin{array}{l}\text { Regional minerals are very } \mathrm{Sn} \text { rich and contain } \\
\text { a low amount of impurities. }\end{array}$ \\
\hline $\begin{array}{l}\text { Caerloggas Downs, } \\
\text { Cornwall, SW } \\
\text { England (Malham, } \\
\text { 2010; Tylecote } \\
\text { et al., 1989) }\end{array}$ & $\begin{array}{l}\text { Early Bronze } \\
\text { Age }(\sim 1600 \\
\text { BCE })\end{array}$ & $\begin{array}{l}\text { Seven pieces of } \\
\text { slag }\end{array}$ & $\begin{array}{l}\text { Found at a ritual } \\
\text { enclosure (burial) }\end{array}$ & $\begin{array}{l}\text { Slag with } \sim 41 \% \mathrm{Sn} \text {; begin to soften at } 1050{ }^{\circ} \mathrm{C} \text {. } \\
\text { Glassy microstructure, iron silicate slag with } \\
\text { pure metallic tin prills (some visible with the } \\
\text { nacked eye). Single area scan } \sim 40 \% \mathrm{SnO}_{2} \sim 31 \% \\
\mathrm{SiO}_{2} ; \sim 13 \% \mathrm{Al}_{2} \mathrm{O}_{3} ; 4 \% \mathrm{FeO} ; \sim 3 \% \mathrm{~W} ; \sim 1.5 \% \mathrm{TiO}_{2} \text {; } \\
\text { others }<1 \% \text {. }\end{array}$ & $\begin{array}{l}\text { Rich cassiterite ores, frequent presence of } \mathrm{W} \\
\text { and Ti. Very low amounts of } \mathrm{Ta} \text { and } \mathrm{Nb}(<0.1 \%) \text {. }\end{array}$ \\
\hline $\begin{array}{l}\text { Dean Moor, Devon, } \\
\text { SW England } \\
\text { (Malham, 2010) }\end{array}$ & $\begin{array}{l}\text { Late Bronze } \\
\text { Age }\end{array}$ & $\begin{array}{l}\text { Single tiny } \\
\text { bead of slag } \\
\text { with reddish } \\
\text { colour; } \sim 3 \mathrm{~mm} \\
\text { size }\end{array}$ & $\begin{array}{l}\text { Discovered in a } \\
\text { hearth inside one } \\
\text { roundhouse of a } \\
\text { LBA settlement }\end{array}$ & (no analyses available) & $\begin{array}{l}\text { Rich cassiterite ores, frequent presence of } \mathrm{W} \\
\text { and } \mathrm{Ti} \text { (Ti possibly in higher amounts than in } \\
\text { Cornish ores). Very low amounts of Ta and } \mathrm{Nb} \\
(<0.1 \%) \text {. }\end{array}$ \\
\hline
\end{tabular}

heterogeneous at micro and macro levels, and that both composition and microstructure are strongly influenced by the geochemistry of the ores used (Malham, 2010). The type of gangue minerals in the ore specimens, the manner in which the ores were processed, as well as fluxes added and smelting technology, can also directly influence the characteristics of the slags.

The rich cassiterite resources of Iberia were exploited at least since classical times. Ancient authors such as Strabo (end of 1st century BCE to beginning of 1 st century CE) and Pliny the Elder (1st century $\mathrm{CE}$ ) commented on the richness in ores of the Iberian Peninsula and on the Cassiterides or Tin Islands, representing the first vague knowledge of the Greeks that tin was found overseas somewhere in or off Western Europe (Comendador Rey et al., 2008). Pliny the Elder in his work Historia Naturalis (Book XXIV) (Pliny, 1938) specified the origin of the tin traded to the Mediterranean by the Punic as "it is now known that it is a product of Lusitania and Gallecia”. These two regions represent the modern northern and central Portugal, and the Spanish Galicia and Extremadura regions, which are also coincident with the Iberian tin belt.

The early presence, from Late Bronze Age, of artefacts with Mediterranean affiliations at inland tin-rich contexts have frequently been suggested to relate to trade routes involving mineral sources (Vilaça, 2006; Senna-Martínez, 2011). Also, Phoenician settlements in the Portuguese Atlantic coast from the early first millennium BCE are known, that provided navigable access to both the sea and the inland tin-rich areas through major rivers, and acted as trading-stations (Arruda, 2009; Wachsmann et al., 2009).

Indirect field evidence for early tin exploitations has been found during archaeological excavations or during the (re)opening of mining works for tungsten and tin exploitation during the first half of the 20th century. For the area to the north of the Douro River more than twenty tin mining sites were described to have "old" works in the mining engineers' reports (Meunier, 2011). These 
mining reports in some occasions also included the finding of archaeological remains, most frequently Roman coins and ceramics. Findings of earlier periods include the crushing and grinding stone tools at Tuella Tin Mines (Ervedosa, Vinhais, N Portugal) that were believed to have served to process cassiterite during the protohistoric/Bronze Age(?) period (Veiga Ferreira and Castro, 1949; Fernandes, 2008); the Late Bronze Age dagger found during tin mining works at Lameiras (Orgens, Viseu, C Portugal) (Vilaça et al., 2014); or the mining stone tools found at the Late Bronze Age/ Orientalising site of Cerro de San Cristobal (Logrosán, Central Spain), a settlement established adjacent to a cassiterite mining site (Merideth, 1996; Rodríguez Díaz et al., 2013).

Despite the indirect evidences for cassiterite exploitation, clear material evidence for tin smelting is so far very scarce in the Iberian Peninsula, as elsewhere. Besides the Roman slags from Centum Cellas (Merideth, 1996), only the Carvalhelhos hillfort (Boticas, N Portugal) has been described in the literature to have tin slags and ore (Maia e Costa, 1966; Beagrie, 1985; Tylecote et al., 1989; Rovira, 2007).

Carvalhelhos hillfort is an Iron Age site where numerous slags were found during old archaeological works, and approximately $200 \mathrm{~kg}$ of cassiterite (nowadays lost) were found by local inhabitants in a cache at a slope of the site facing a nearby stream (Ribeira das Lameiras) (Santos Júnior, 1984). An early analytical study of one of the slags was made by Maia e Costa (1966) who attributed it to tin production. Yet, the slag analysed showed a relatively low $\mathrm{Sn}$ content $\left(\sim 2 \mathrm{wt} \% \mathrm{SnO}_{2}\right)$ and a high Fe content $\left(\sim 65\right.$ wt\% $\left.\mathrm{Fe}_{2} \mathrm{O}_{3}\right)$ causing Tylecote et al. (1989) to suggest that the slag was possibly a product of iron metallurgy and not one of tin. In contrast, Maia e Costa (1966) had argued that the relatively low Sn content was due to the presence of unreacted Fe oxides (hematite or limonite ores) that were intentionally added (in excess) to serve as a flux in the absence of $\mathrm{Ca}$, suggesting that it was an ingenious way to overcome the lack of knowledge on the cassiterite ores composition, namely their silica content.

The Carvalhelhos hillfort is located in a region with a high density of tin ore occurrences (Fig. 1b). Despite its location and the large amount of slags found at the site, since the 1960's and the later 1980's, the archaeological materials and the site never underwent a re-evaluation. Given the importance that tin metal had for bronze production in ancient times and the limited known regions with tin resources in the Old World, a re-evaluation of the site and its metallurgical related materials appears to be mandatory.

Thus, in the present work, detailed analyses of tin slags and a few other materials from the site will be presented. Also, the geological context of the site will be described, and a pilot field survey to collect cassiterite in nearby locations included. The analyses of these cassiterite samples and associated minerals provide complementary information to the study of the tin slags composition. The aim is to provide new and more comprehensive data from Carvalhelhos hillfort to allow a clearer recognition of the site as related to ancient tin production.

\section{Details on Carvalhelhos hillfort and archaeological materials selected for analysis}

The Carvalhelhos hillfort is located in Northern Portugal, in the Beça parish (Boticas municipality, Vila Real district, Trás-os-Montes region) and was excavated between the early 1950's and 1980's, through several campaigns directed by J.R. dos Santos Júnior (Santos Júnior, 1984).

The site possesses an outstanding defensive complex system composed by two walls, three ditches and a chevaux-de-frise field, despite having a very small inner area (about 1 ha) (Fig. 2a). Due to the rather emblematic defensive structures, the site was classified by the Portuguese government as of national interest (Imóvel de Interesse Público) in 1951.

Inside the settlement a number of circular and rectangular domestic structures were found, and many materials were exhumed from the site, but unfortunately no detailed records were made. Additionally, the archaeological materials and documents were distributed among various regional museums and institutions during the decades of excavations, hindering a comprehensive evaluation of the site. Among the collected materials are several kilograms of slags, fragments of pottery of "castreja" typology attributed to 2 nd century BCE-1st century CE, some metal artefacts such as fibulae, rings and pins, and a few Roman coins that can be dated to 26-25 BCE and 41-54 CE (Fonte, 2015).

In general, the site can be considered one of the numerous NW Iberian Iron Age hillforts ("castros" in Portuguese and Spanish), many of which appear to have been constructed during the 8th century BCE, or even earlier (during the Late Bronze Age), and were occupied until the early Roman presence in the NW Iberian territory (Jordá Pardo et al., 2014). Based on the recent re-interpretation of the material culture of the site (Fonte, 2015), a more restricted chronology for the Carvalhelhos hillfort has been proposed, between the 2nd century BCE and the 1 st century CE.

In NW Iberia, the hillforts are normally located in elevated positions. However, the Carvalhelhos hillfort is located at a slope near a stream bend (Ribeira das Lameiras), with a very limited visual prominence (Fonte, 2015). From the site facing the stream there is an easy accessibility but the mobility along the stream would be difficult since the valley is quite deep. Agricultural productivity in the vicinity of the hillfort was presumably limited due to the steep slope of the terrain and its rocky characteristics.

After years of excavations, Santos Júnior developed a familiarity with the region, and concluded that "the inhabitants of Carvalhelhos were skilled miners who exploited the cassiterite tin ore (...) which was exploited in some pits dug on the periphery of the village". He interpreted the cache with $200 \mathrm{~kg}$ of cassiterite as a "hiding place made by the inhabitants in the imminence of an attack, possibly by the Romans" (author's translation) (Santos Júnior, 1984).

For the present study, three slag fragments (A-S1, A-S2 and AS3) that resembled the descriptions of early tin slags, namely blackish colour and vitreous aspect (Tylecote et al., 1989), were selected for detailed analysis. Also, a reddish slag (A-Fe), likely from iron metallurgy, was selected to check if this type of slag has small amounts of Sn, and thus provide a connection to the slag studied earlier by Maia e Costa (1966). Additionally, two ceramic fragments (A-C1 and A-C2) were selected from a large quantity of ceramic fragments which could have been part of some smelting structure and/or metallurgical vessels, but which fragmentary state did not allow a clear evaluation. The bulky shape of the selected fragments and the absence of a slagged layer would rather relate them to some structure and not a crucible. The larger of these fragments (AC1) shows a dense side with a blackish colour and opposite a powdery side with grey colour. The smaller sample (A-C2) presents two distinct areas of different colours, one blackish and the other reddish. The reddish side shows some magnetism when brought close to a magnet. Images of the selected materials are presented in Fig. 2b.

\section{Tin ores and geological context of Carvalhelhos}

The most important mineral source of tin is cassiterite $\left(\mathrm{SnO}_{2}\right)$, a chemically stable and heavy mineral with a density between 6.8 and $7.1 \mathrm{~g} / \mathrm{cm}^{3}$. Pure tin oxide is colourless (or white in powdered form), but cassiterite in its natural state is almost always brown or black owing to the presence of impurities in the form of oxides. 
(a)
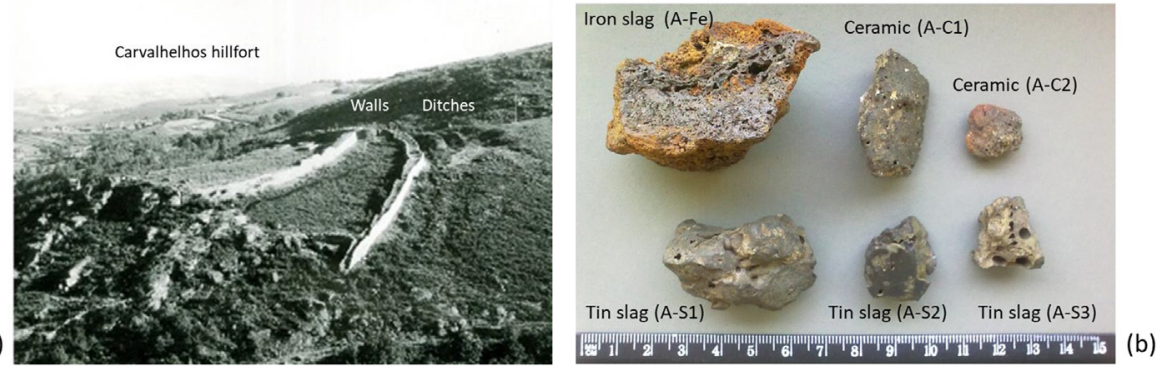

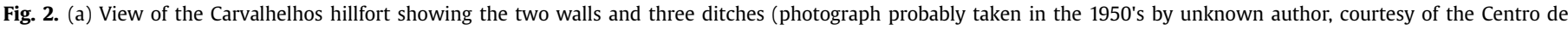
Memória de Torre de Moncorvo); (b) archaeological materials selected for analysis, which include three tin slags, one iron slag and two ceramic fragments.

Analyses of cassiterite samples from various Iberian Hercynian Massif deposits have shown that natural cassiterite may contain significant amounts of $\mathrm{Nb}, \mathrm{Ta}, \mathrm{W}$ or other elements, such as Fe, Ti, In, Hg. Niobium and tantalum can be present in mineral exsolutions, inclusions or as substitution of tin in the cassiterite lattice (Murciego et al., 1997; Izoret et al., 1985; Neiva, 1996).

In a radius of $5 \mathrm{~km}$ from Carvalhelhos site there are several tinrelated mineralisation locations, and within a radius of $20 \mathrm{~km}$ towards south and west the number of tin-related mineralisation increases substantially (Fig. 3a). The cassiterite is present in primary and secondary deposits, and within the primary deposits it is present in hydrothermal quartz veins and in granitic aplitepegmatite formations (Teixeira, 1974; Ferreira and Noronha, 1987; Martins and Lima, 2011; Martins et al., 2011). Also, cassiterite frequently occurs in greisens surrounding the pegmatites.

In the region, several mineralisations have been extensively mined for Sn and W until the middle of the 20th century and to less extent after the 2nd World War (Charoy et al., 1992; Pires, 1995). Generally, mining in the region did not involve sophisticated or very deep works. The mining activities included superficial hand picking of weathered rocks, and was regularly performed "parttime" by local inhabitants. When more organised exploitation was attempted, diggings did never reached deeper than $20 \mathrm{~m}$ (Ferreira and Noronha, 1987). In some areas, along with cassiterite, tantalum-rich minerals were also mined (Pires, 1995). Although mining was done predominantly at primary deposits it was sometimes also performed at alluvial placers (Ferreira and Noronha, 1987). About $5 \mathrm{~km}$ north of Carvalhelhos, in the Bessa mining area, large cassiterite pebbles over $5 \mathrm{~cm}$ in diameter were still being collected during the mid-20th century.

A geochemical study of streambed sediments made by the national geological services in the first half of the 1990's (some decades after the mining works ceased in the region) to prospect for $\mathrm{Li}$ sources, analysed the content of Ta, Nb, Sn, W, Li and U from 592 sediment samples (Fig. 3b) (Pires, 1995). A statistical method was used to determine geochemical anomalies from the background and five areas were detected with Sn anomalies, one of them Carvalhelhos. In the Carvalhelhos area, two samples with Sn anomalies were located at the vicinity of the Carvalhelhos hillfort, in Ribeira das Lameiras. The study concluded that $\mathrm{Sn}$ anomalies appeared to be strongly connected to recent (20th century) mining activities. Nevertheless, in light of recent studies (Monna et al., 2014), we should not discard the idea that some of these places could also be related to more ancient activities. The geochemical study did also conclude that $\mathrm{Ta}$ and $\mathrm{Nb}$ were strongly correlated, and primary sources of $\mathrm{Sn}$ were related to $\mathrm{Ta}$ and $\mathrm{Nb}$ in some cases, while in others Sn was strongly associated to W. In the Carvalhelhos area, the primary sources were described as being preferentially connected to $\mathrm{W}$ in quartz veins, with such places located in the $\mathrm{W}-\mathrm{S}$ side of the hill where Carvalhelhos hillfort is placed.

\section{Local geological survey}

For the present study five cassiterite samples were collected from five places in the $20 \mathrm{~km}$ range from the Carvalhelhos hillfort. Details of the samples and their geological context can be found in Table 2(a). From these five, two were taken from secondary sources (C1 and C2) and three samples were taken from primary sources (C3, C4 and C5). The two samples from secondary sources were collected in places with Sn anomalies (Pires, 1995): (C1) at Bessa

(a)

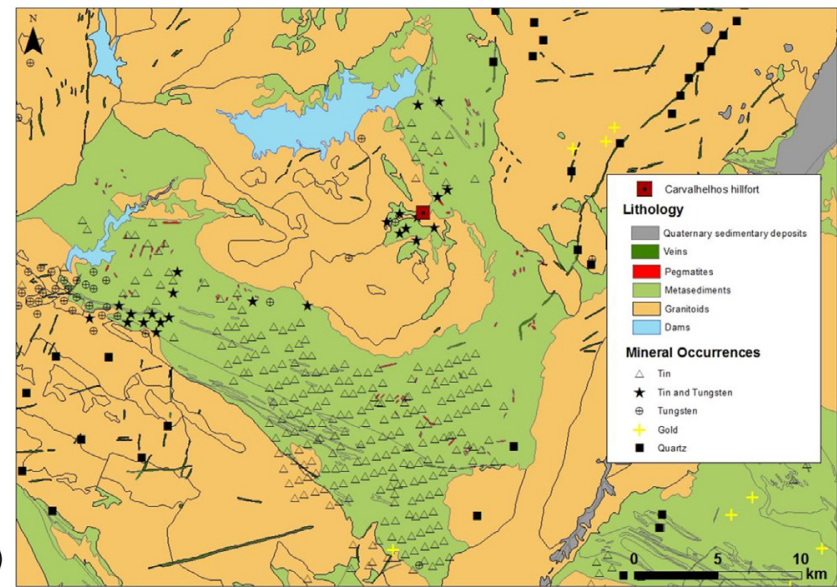

(b)

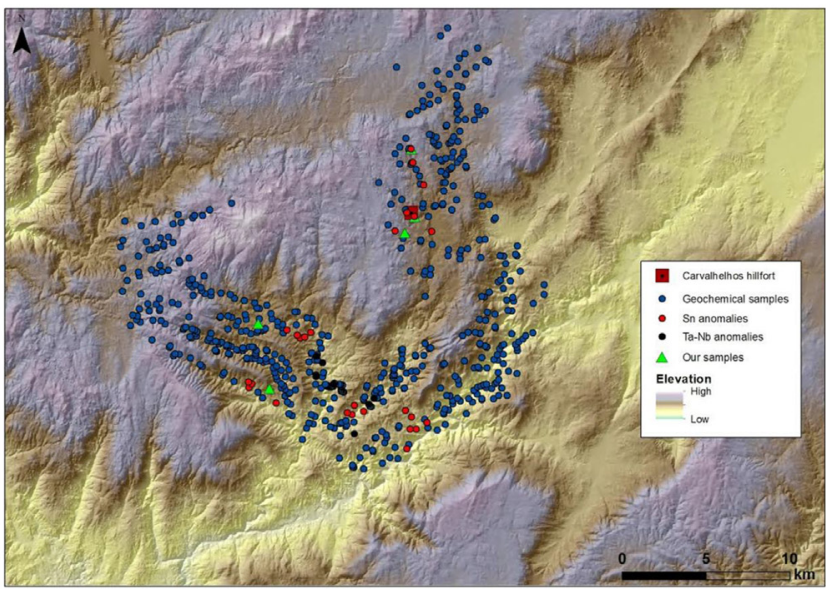

Fig. 3. Maps of the Carvalhelhos region with geological, topographic and mineral information: (a) lithological information and location of mineral occurrences of Sn, SnW, W, Au and Quartz (based on geological database SIORMINP-LNEG); (b) topographic information with location of streambed sediments samples analysed in Pires (1995) with annotated Sn and Ta-Nb anomalies. Locations of cassiterite samples studied in the present paper are also annotated (our samples). 
Table 2

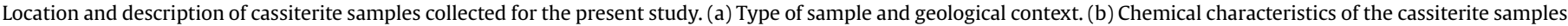
collected.

\begin{tabular}{|c|c|c|c|c|c|c|c|c|}
\hline \multirow[t]{2}{*}{ N. ${ }^{\circ}$} & \multirow{2}{*}{$\begin{array}{l}\text { Location of } \\
\text { sample }\end{array}$} & \multicolumn{3}{|l|}{ (a) } & \multicolumn{4}{|l|}{ (b) } \\
\hline & & Type of sample & $\begin{array}{l}\text { Geological } \\
\text { context }\end{array}$ & Other information & $\begin{array}{l}\text { Cassiterite } \\
\text { crystals }\end{array}$ & $\begin{array}{l}\text { Micro-inclusions } \\
\text { in cassiterite }\end{array}$ & Other associated minerals & Notes \\
\hline $\mathrm{C} 1$ & $\begin{array}{l}\text { Carvalhais, } \\
\text { Couto } \\
\text { mineiro do } \\
\text { Bessa ( } 4 \mathrm{~km} \mathrm{~N} \\
\text { Carvalhelhos) }\end{array}$ & $\begin{array}{l}\text { Small } \\
\text { cassiterite } \\
\text { grains } \\
(<3 \mathrm{~mm})\end{array}$ & $\begin{array}{l}\text { Secondary } \\
\text { deposit. Obtained } \\
\text { by panning. }\end{array}$ & $\begin{array}{l}\text { In the immediacy of } 20 \text { th } \\
\text { century mining activities. Place } \\
\text { of previous geochemical } \\
\text { sampling with results showing } \\
\text { Sn anomaly. }\end{array}$ & $\begin{array}{l}\text { Very pure } \\
\text { cassiterite }\end{array}$ & Zircon with Hf & $\begin{array}{l}\text { Quartz; Large size } \\
\text { columbite; Rulite with } \\
\text { cassiterite inclusions; } \\
\text { Ciclocilicate with zircon } \\
\text { and monazite inclusions; } \\
\text { Ilmenite }\end{array}$ & $\begin{array}{l}\text { The purest cassiterite } \\
\text { crystals studied. }\end{array}$ \\
\hline $\mathrm{C} 2$ & $\begin{array}{l}\text { Ribeira de } \\
\text { Lameiras, } \\
\text { Carvalhelhos }\end{array}$ & $\begin{array}{l}\text { Small } \\
\text { cassiterite } \\
\text { grains } \\
(<3 \mathrm{~mm})\end{array}$ & $\begin{array}{l}\text { Secondary } \\
\text { deposit. Alluvial. } \\
\text { Obtained by } \\
\text { panning. }\end{array}$ & $\begin{array}{l}\text { Stream that passes at } \\
\text { Carvalhelhos site. Place of } \\
\text { previous geochemical sampling } \\
\text { with results showing Sn } \\
\text { anomaly. }\end{array}$ & $\begin{array}{l}\text { Cassiterite } \\
\text { with Ta and } \\
\mathrm{Nb} \text { in } \\
\text { crystal } \\
\text { structure }\end{array}$ & (not observed) & $\begin{array}{l}\text { Ilmenite with zircon and } \\
\text { monazite inclusions; } \\
\text { Ciclocilicates with zircon } \\
\text { and monazite inclusions. }\end{array}$ & $\begin{array}{l}\text { High and dispersed } \\
\text { Ta and Nb contents in } \\
\text { different grains. High } \\
\text { Ti contents. }\end{array}$ \\
\hline $\mathrm{C} 3$ & $\begin{array}{l}\text { "Ancient } \\
\text { exploitation" } \\
\text { ( } 2 \text { km SW } \\
\text { Carvalhelhos) }\end{array}$ & $\begin{array}{l}\text { Cassiterite } \\
\text { grains } \\
(<5 \mathrm{~mm}) \\
\text { among quartz } \\
\text { with altered } \\
\text { arsenopyrite }\end{array}$ & $\begin{array}{l}\text { Primary deposit. } \\
\text { Hydrothermal(?)/ } \\
\text { Pegmatite }\end{array}$ & $\begin{array}{l}\text { Site depicted in a } 1904 \\
\text { prospector's map as "ancient } \\
\text { exploitation". Characterised by } \\
\text { a worked area of } \sim 50 \mathrm{~m} \\
\text { diameter and up to } \sim 2 \mathrm{~m} \text { depth. }\end{array}$ & $\begin{array}{l}\text { Very pure } \\
\text { cassiterite }\end{array}$ & $\begin{array}{l}\text { W-rich inclusions; } \\
\text { Bi-As inclusions; } \\
\text { Ti-Nb-rich } \\
\text { inclusions }\end{array}$ & $\begin{array}{l}\text { Quartz; Feldspar; } \\
\text { Arsenopyrite and Fe-As } \\
\text { alteration products }\end{array}$ & $\begin{array}{l}\text { Absence of Ta. } \\
\text { Presence of As in } \\
\text { weathered associated } \\
\text { minerals. }\end{array}$ \\
\hline $\mathrm{C} 4$ & $\begin{array}{l}\text { Dornelas } \\
\text { (9 km SW } \\
\text { Carvalhelhos) }\end{array}$ & $\begin{array}{l}\text { Large } \\
\text { cassiterite } \\
\text { grains in } \\
\text { pegmatite }\end{array}$ & $\begin{array}{l}\text { Primary deposit. } \\
\text { Pegmatite. }\end{array}$ & $\begin{array}{l}\text { Sample provided by an local } \\
\text { miner. }\end{array}$ & $\begin{array}{l}\text { Cassiterite } \\
\text { with Ta and } \\
\mathrm{Nb} \text {. It has } \\
\text { higher } \\
\text { amount of } \\
\mathrm{Ta}\end{array}$ & $\begin{array}{l}\text { Presence of } \\
\text { columbite and } \\
\text { tapiolite. Zircon } \\
\text { with Hf }\end{array}$ & $\begin{array}{l}\text { Quartz; Feldspar; } \\
\text { Muscovite }\end{array}$ & $\begin{array}{l}\text { High Ta and Nb } \\
\text { contents. Absence of } \\
\text { Ti. }\end{array}$ \\
\hline C5 & $\begin{array}{l}\text { Gondiães } \\
\text { (13 km SW } \\
\text { Carvalhelhos) }\end{array}$ & $\begin{array}{l}\text { Small } \\
\text { cassiterite } \\
\text { grains } \\
(<5 \mathrm{~mm}) \text { in } \\
\text { albite }\end{array}$ & $\begin{array}{l}\text { Primary deposit. } \\
\text { Weathered } \\
\text { pegmatite }\end{array}$ & $\begin{array}{l}\text { Place that shows evidences of } \\
\text { past mining works (including } \\
\text { very narrow vertical pits). } \\
\text { Nowadays is being explored for } \\
\text { the ceramic industry. }\end{array}$ & $\begin{array}{l}\text { Cassiterite } \\
\text { with } \mathrm{Ta} \text { and } \\
\mathrm{Nb}\end{array}$ & $\begin{array}{l}\text { Presence of many } \\
\text { columbite group } \\
\text { minerals (various } \\
\text { Ta/Nb ratios); } \\
\text { Zircon with Hf }\end{array}$ & Quartz; Albite; Muscovite & $\begin{array}{l}\text { Cassiterite in small } \\
\text { grains dispersed in a } \\
\text { weathered matrix of } \\
\text { white colour. Of easy } \\
\text { hand sorting. }\end{array}$ \\
\hline
\end{tabular}

(4 km north of Carvalhelhos) and (C2) Ribeira das Lameiras (in Carvalhelhos). Both samples from secondary deposits were collected by a traditional panning method and consisted of small cassiterite grains of $<3 \mathrm{~mm}$ size.

Two of the samples from primary sources were collected in places with old mining vestiges (prior to the 20th century). The first sample (C3) was collected at an "ancient exploitation" location $2 \mathrm{~km} \mathrm{SW}$ to the Carvalhelhos hillfort, based on a map dating to 1904 made by mining prospectors. The sampling place correspond to a $\sim 50 \mathrm{~m}$ diameter area, which had been worked to about $2 \mathrm{~m}$ in depth. A sample with cassiterite grains ranging from 1 to $5 \mathrm{~mm}$ size among quartz grains was collected. The second sample (C4) comes from Gondiães, a more distant location ( $15 \mathrm{~km}$ SW Carvalhelhos), from a site located near the top of a mountain slope with old mining work vestiges and with a modern exploitation for the ceramic industry. This sample consisted of small black grains of cassiterite in a white weathered pegmatite matrix that could be very easily disintegrated by hand.

The last sample (C5) was provided by a former miner from Dornelas ( $9 \mathrm{~km}$ southwest of Carvalhelhos). Images of cassiterite samples from the three primary locations are shown in Fig. 4.

\section{Analytical methods}

Analyses by wavelength dispersive X-ray fluorescence spectrometry (WDXRF), variable pressure scanning electron microscopy with an energy-dispersive spectrometer (SEM-EDS) and powder and micro X-ray diffraction (XRD) were performed on the archaeological and geological samples regarding their nature and amount. In Table 3, the type of analysis undertaken for each sample is shown.

The results of the elemental analyses are presented in the form of normalised oxides in wt.\%. In the case of elements that can show more than one state of oxidation, the most oxidised state was used. Still, when appropriate, results in other oxidation states can be presented and are annotated.

\subsection{WDXRF}

Elemental analysis by WDXRF were performed on samples of the tin slags, iron slag, ceramics and cassiterite samples C2, C3 and C6. Samples were crushed and analysed as fine particles to minimise material heterogeneities and crystalline effects.

Analyses were carried out in a PANalytical XRF-WDS $4 \mathrm{~kW}$ AXIOS sequential spectrometer (PANalytical B.V., Almelo, The Netherlands) using a Rh X-ray tube and 4 analyser crystals. Analyses were performed under a He flow and in scanning mode to allow detecting a maximum number of elements in the sample $(Z>8)$. Spectra deconvolution by the iterative least squares method and elemental quantification based on the fundamental parameter approach with 15 certified secondary standards were performed with the SuperQ software package using the PANalytical standardless analytical program IQ+ (PANalytical B.V., Almelo, The Netherlands). This approach allowed a multi-elemental analysis of the samples available in different amounts and of complex chemical compositions in a relatively fast and simple mode. Provided the high resolution of the technique, spectral interferences as overlaps of characteristic X-rays from different elements were negligible and elements could be detected even if present in very low amounts (ppm).

The analysis methodology was assessed by analysing three certified reference materials as unknown samples that contained most relevant elements present in the archaeological and geological samples. Results are reported in Table 4 where the average of five analyses, standard deviation, reproducibility, and accuracy are shown. The reproducibility is regularly within the $97-99 \%$ range, 

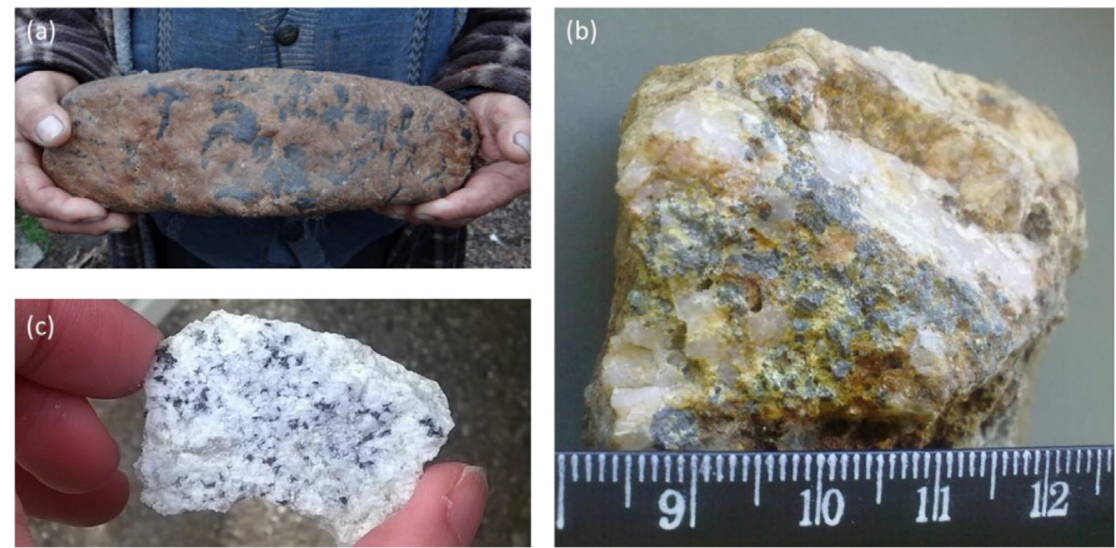

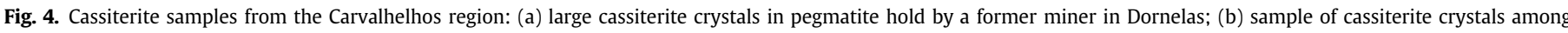
quartz and altered arsenopyrite from the "ancient exploitation"; (c) sample of cassiterite crystals in altered pegmatite from Gondiães.

Table 3

Summary of analytical methods used for the samples characterisation.

\begin{tabular}{|c|c|c|c|c|c|}
\hline & & \multirow[t]{2}{*}{ WDXRF } & \multirow[t]{2}{*}{ SEM-EDS } & \multicolumn{2}{|l|}{ XRD } \\
\hline & & & & powder & micro mode \\
\hline \multicolumn{6}{|c|}{ Archaeological samples } \\
\hline A-S1 & Tin slags & $\mathrm{X}$ & $\mathrm{X}$ & $\mathrm{X}$ & \\
\hline A-S2 & & $\mathrm{X}$ & $\mathrm{X}$ & $\mathrm{X}$ & \\
\hline A-S3 & & $\mathrm{X}$ & $\mathrm{X}$ & $\mathrm{X}$ & \\
\hline $\mathrm{A}-\mathrm{Fe}$ & Iron slag & $\mathrm{X}$ & $\mathrm{X}$ & $\mathrm{X}$ & $\mathrm{X}$ \\
\hline $\mathrm{A}-\mathrm{C} 1$ & Ceramics & $\mathrm{X}$ & & $\mathrm{X}$ & $\mathrm{X}$ \\
\hline$A-C 2 b$ & & $\mathrm{X}$ & & $\mathrm{X}$ & $\mathrm{X}$ \\
\hline $\mathrm{A}-\mathrm{C} 2 \mathrm{r}$ & & $\mathrm{X}$ & & $\mathrm{X}$ & $\mathrm{X}$ \\
\hline \multicolumn{6}{|c|}{ Cassiterite samples } \\
\hline $\mathrm{C} 1$ & Carvalhais, Couto mineiro do Bessa & & $\mathrm{X}$ & & \\
\hline $\mathrm{C} 2$ & Ribeira de Lameiras, Carvalhelhos & $\mathrm{X}$ & $\mathrm{X}$ & & \\
\hline $\mathrm{C} 3$ & "Ancient exploitation" & $\mathrm{X}$ & $\mathrm{X}$ & & \\
\hline $\mathrm{C} 4$ & Dornelas & & $\mathrm{X}$ & & \\
\hline $\mathrm{C} 5$ & Gondiães & $X$ & $X$ & & \\
\hline
\end{tabular}

Table 4

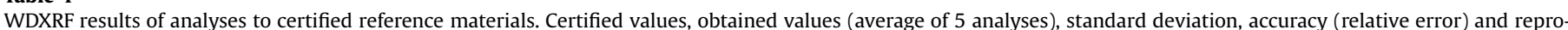
ducibility are reported for each element.

\begin{tabular}{|c|c|c|c|c|c|c|c|c|c|c|c|c|c|c|}
\hline Silicate glass (BR C3) & & $\mathrm{Al}_{2} \mathrm{O}_{3}$ & $\mathrm{SiO}_{2}$ & $\mathbf{P}_{2} \mathbf{O}_{5}$ & $\mathbf{K}_{2} \mathbf{O}$ & & $\mathrm{TiO}_{2}$ & & $\mathrm{Fe}_{2} \mathrm{O}_{3}$ & & $\mathrm{As}_{2} \mathrm{O}_{3}$ & $\mathrm{Nb}_{2} \mathrm{O}_{5}$ & & \\
\hline Certified (wt.\%) & & 27.1 & 9.9 & 15.6 & 6.9 & & 0.1 & & 5.4 & & 0.78 & 0.6 & & \\
\hline Obtained (wt.\%) & & 27.3 & 8.47 & 14.4 & 8.33 & & 0.09 & & 7.81 & & 0.83 & 0.75 & & \\
\hline STDEV & & 0.54 & 0.1 & 0.23 & 0.13 & & 0.02 & & 0.24 & & 0.03 & 0.03 & & \\
\hline Repr. (\%) & & 98 & 99 & 98 & 98 & & 82 & & 97 & & 97 & 96 & & \\
\hline Acc. $(\%)$ & & 1 & 14 & 8 & 21 & & 10 & & 45 & & 6 & 25 & & \\
\hline Tin ore (BCS-355) & & Al & $\mathbf{S i}$ & & & Ca & & & $\mathbf{F e}$ & Cu & As & & Sn & $\mathbf{w}$ \\
\hline Certified (wt.\%) & & 4.12 & 7.14 & & & 2.63 & & & 17.1 & 0.085 & 0.14 & & 31.4 & 0.35 \\
\hline Obtained (wt.\%) & & 3.45 & 5.68 & & & 2.64 & & & 22.2 & 0.095 & 0.09 & & 27.5 & 0.33 \\
\hline STDEV & & 0.06 & 0.12 & & & 0.08 & & & 0.4 & 0.007 & 0.02 & & 0.24 & 0.03 \\
\hline Repr. (\%) & & 98 & 98 & & & 97 & & & 98 & 93 & 73 & & 99 & 92 \\
\hline Acc. $(\%)$ & & 16 & 20 & & & 0.5 & & & 30 & 12 & 36 & & 13 & 5 \\
\hline Blast-furnace slag (SMU 7-1-013) & MgO & $\mathbf{A l}_{2} \mathbf{O}_{3}$ & $\mathrm{SiO}_{2}$ & & & CaO & TiO & Mno & & & & & & \\
\hline Certified (wt.\%) & 8 & 38.6 & 20.3 & & & 28.7 & 0.78 & 0.26 & & & & & & \\
\hline Obtained (wt.\%) & 4.4 & 34 & 22.2 & & & 35.8 & 0.94 & 0.31 & & & & & & \\
\hline STDEV & 0.12 & 0.51 & 0.23 & & & 0.41 & 0.06 & 0.04 & & & & & & \\
\hline Repr. (\%) & 97 & 98 & 99 & & & 99 & 94 & 86 & & & & & & \\
\hline Acc. (\%) & 45 & 12 & 9 & & & 25 & 21 & 17 & & & & & & \\
\hline
\end{tabular}

allowing a good inter-comparison of the samples. Accuracy for most elements shows a relative error that varies from 1 to $25 \%$. The accuracy of the method was considered as acceptable since it was used for samples of very diverse chemical compositions and strong heterogeneity, relativising the significance of single or absolute chemical values.

\subsection{SEM-EDS}

Micro-elemental analysis and microstructure examination was performed by SEM-EDS on polished surfaces of samples of the tin slags, iron slag, and cassiterite samples $\mathrm{C} 3, \mathrm{C} 4$ and $\mathrm{C} 5$, without gold or carbon coating. In case of the alluvial cassiterite samples ( $\mathrm{C} 1$ and 
C2) and associated minerals, analyses were made without surface preparation.

The SEM examinations were conducted in a variable pressure scanning electron microscope HITACHI S-3700N (Hitachi Ltd., Tokyo, Japan) with a secondary electrons detector (SE), backscattered electrons detector (BSE) and an energy dispersive spectrometer (EDS). The EDS is an XFlash 5010 Silicon Drift Detector (SDD) with a resolution of $129 \mathrm{eV}$ at $\mathrm{Mn} \mathrm{K} \alpha$, from Bruker (Bruker Nano GmbH, Berlin, Germany). Experimental conditions were at $20 \mathrm{kV}$ accelerating voltage, $100-120 \mu \mathrm{A}$ emission current and $10-12 \mathrm{~mm}$ working distance. The chamber pressure varied from $30 \mathrm{~Pa}$ to high vacuum, depending on the conductivity of the materials analysed. Standardless semi-quantitative quantifications were made using ZAF correction procedure.

\section{3. $X R D$}

X-ray diffraction analyses were performed on tin slags, iron slag and ceramics to identify crystalline phases. Analysis were made in the same samples that had previously been analysed as powder in WDXRF or in samples that had a small polished surface analysed by SEM-EDS. For the latter, the analysis was made in a micro-XRD mode and no further surface preparation was performed. In the case of the ceramic samples, both modes were used.

The XRD patterns were recorded with a Bruker D8 Discover diffractometer (Bruker AXS GmbH, Karlsruhe, Germany) using $\mathrm{Cu}$ $\mathrm{K} \alpha$ radiation, operating at a $2 \theta$ angular range of $3-75^{\circ}$, step size of $0.05^{\circ}$ and a step time of $1 \mathrm{~s}$ in a LYNXEYE linear detector, acting as 192 individual detectors. In the micro-XRD experiments, a Göbel mirror and a $0.3 \mathrm{~mm}$ collimator were used that direct a small parallel X-ray beam onto the sample. The identification of crystalline phases was performed using the DIFFRAC.EVA software (EVA, Bruker AXS GmbH, Karlsruhe, Germany) and the ICDD PDF-2 database (ICDD, Newtown Square, PA, USA).

\section{Results and discussion}

\subsection{Tin slags}

The WDXRF analyses of the three slag fragments (A-S1, A-S2 and A-S3) are presented in Table 5. Two samples from each slag were analysed. Results show clear and relatively high Sn contents (4-24\% $\mathrm{SnO}_{2}$ ), as expected for early tin slags (Tylecote et al., 1989). They also show high $\mathrm{Ta}$ and $\mathrm{Nb}$ contents $\left(11-14 \% \mathrm{Ta}_{2} \mathrm{O}_{5}\right.$ and $4-8 \%$ $\mathrm{Nb}_{2} \mathrm{O}_{5}$ ). Other elements present are $19-37 \% \mathrm{SiO}_{2}, 15-16 \% \mathrm{Fe}_{2} \mathrm{O}_{3}$, $8-13 \% \mathrm{Al}_{2} \mathrm{O}_{3}, \sim 6 \% \mathrm{TiO}_{2}, 2-3 \% \mathrm{MnO}, 2-3 \% \mathrm{~K}_{2} \mathrm{O}, 1-2 \% \mathrm{WO}_{3}$ and $<1 \%$ $\mathrm{MgO}, \mathrm{P}_{2} \mathrm{O}_{5}, \mathrm{CaO}$ and $\mathrm{ZrO}_{2}$. Elements that were detected in vestigial quantities are $\mathrm{Ce}, \mathrm{Y}, \mathrm{Nd}$ and $\mathrm{Hf}$. For each slag, the two samples analysed show similar results. The higher variations found in A-S1 can be attributed to a higher degree of compositional heterogeneity of this slag.

The SEM-EDS analyses of polished surfaces show that the three slags have similar microstructures, with a common type of structure next described as of type I. Some variations to this microstructure were found in some areas of the slags, next described as regions of type II and III.

Type I region was the most common, and is composed of a vitreous silica-alumina-tin-rich matrix with thin tantalum-rich dendrites and some isolated metallic tin globules (Fig. 5a). The vitreous matrix shows compositional gradients in the range of $14-18 \%$ $\mathrm{Al}_{2} \mathrm{O}_{3}, 30-36 \% \mathrm{SiO}_{2}, 15-19 \% \mathrm{Fe}_{2} \mathrm{O}_{3}, 15-30 \% \mathrm{SnO}_{2}$, with $\mathrm{MnO}, \mathrm{K}_{2} \mathrm{O}$, $\mathrm{P}_{2} \mathrm{O}_{5}, \mathrm{TiO}_{2}, \mathrm{Na}_{2} \mathrm{O}, \mathrm{MgO}, \mathrm{Nb}_{2} \mathrm{O}_{5}$ and $\mathrm{Ta}_{2} \mathrm{O}_{5}$ totalling $10-18 \%$. The dendrites are Ta-Nb-Ti-rich (further called Ta-rich phase), with a composition in the range of $45-50 \% \mathrm{Ta}_{2} \mathrm{O}_{5}, 17-18 \% \mathrm{Nb}_{2} \mathrm{O}_{5}, 22-25 \%$ $\mathrm{TiO}_{2}, 8-12 \% \mathrm{Fe}_{2} \mathrm{O}_{5}$ and $<1 \% \mathrm{MnO}$. The small metallic Sn globules are frequently in the 5-25 $\mu \mathrm{m}$ diameter range, with larger ones of 30-60 $\mu \mathrm{m}$ diameter. These globules are normally surrounded by a $2-5 \mu \mathrm{m}$ layer of the Ta-rich phase. EDS area analyses of regions of type I showed a composition in the range of $23-25 \% \mathrm{SiO}_{2}, 9-10 \%$ $\mathrm{Al}_{2} \mathrm{O}_{3}, 6-7 \% \mathrm{TiO}_{2}, 18-19 \% \mathrm{Fe}_{2} \mathrm{O}_{5}, 19-21 \% \mathrm{SnO}_{2}, 5-6 \% \mathrm{Nb}_{2} \mathrm{O}_{5}$ and $11-12 \% \mathrm{Ta}_{2} \mathrm{O}_{5}$ (with other elements totalling 5\%). This composition is similar to the one obtained by WDXRF, especially for the samples taken from A-S2 and A-S3 slags. This microstructure shows that liquid immiscibility occurred between metallic $\mathrm{Sn}$ and the remainder of the melt, followed by the formation of a primary solid phase of Ta-rich dendrites. But, in some areas another crystalline phase was formed, showing thin needle-like Fe-rich structure (Fig. 5b). Most likely, this Fe-rich phase represents a second crystallisation product from the smelt.

In type I regions, besides metallic Sn globules, also metallic W was found. In one investigated case both metals appeared together with some Fe forming a three-phase metallic globule (Sn-metal, Wmetal, and W-Fe metal) (Fig. 5c). The globular shape of this inclusion suggests liquid immiscibility between the oxides and the metal Sn-W-Fe. A ternary isothermal section of Fe-Sn-W system at $1200^{\circ} \mathrm{C}$ (Raghavan, 2010) shows two high temperature solid phases, $\mathrm{W}$ and $\mathrm{Fe}_{7} \mathrm{~W}_{6}$, indicating that the slag must have been at temperatures $>1200^{\circ} \mathrm{C}$ so that these phases could have formed from the liquid.

The type II region shows a very fine microstructure with very small grain size (Fig. 6a). EDS area analysis shows a higher $\mathrm{SiO}_{2}$ content $(\sim 30 \%)$ and a lower $\mathrm{SnO}_{2}$ content $(\sim 7 \%)$ than the region type I. This composition shows stronger similarities to the WDXRF analysis of one of the samples taken from the A-S1 slag (sample 1).

The type III microstructure was observed in a peripheral region of one of the slags (Fig. 6b). It is constituted by large euhedral Fe-Tirich or Sn-Ta-Nb-rich (Sn-rich phase) crystals in a glassy matrix very rich in $\mathrm{Sn}\left(\sim 50 \% \mathrm{SnO}_{2}\right)$ without $\mathrm{Nb}$ and Ta. EDS area analysis of this region showed a composition close to $10 \% \mathrm{SiO}_{2}, 6 \% \mathrm{Al}_{2} \mathrm{O}_{3}, 4 \%$ $\mathrm{TiO}_{2}, 13 \% \mathrm{Fe}_{2} \mathrm{O}_{3}, 4 \% \mathrm{Nb}_{2} \mathrm{O}_{5}, 53 \% \mathrm{SnO}_{2}$ and $9 \% \mathrm{Ta}_{2} \mathrm{O}_{5}$. Compared to type I and II regions, type III region has the highest Sn content, but does not contain metallic Sn globules. Likely, it corresponds to a region subjected to more oxidising conditions, resulting in the retention of $\mathrm{Sn}$ in an oxidised state.

Whereas in general the observed microstructures in the Sn slags suggest complete fusion of the smelt, one large inclusion, $\sim 1500 \mu \mathrm{m}$ long and $\sim 500 \mu \mathrm{m}$ wide, which is not chemically homogeneous appears to be part of original ore concentrate (Fig. 7). Two of its largest constituents show Ta, Nb, Fe and Ti or Mn and EDS chemical characterisation show that they are consistent with Ta-rich minerals, namely tapiolite and columbite. Also, some zircon crystals with relatively high contents of Hf are present. Tapiolite and columbite grains are separated by an intermediate phase that besides Ta, Nb, Fe, Mn and Ti from the minerals does also contain Si. This phase is probably a product of the partial decomposition of the minerals during the metallurgical process. Moreover, the zircon crystals show very irregular surfaces, also suggesting partial thermal decomposition. The decomposition of pure zircon occurs at high temperature $\left(1673^{\circ} \mathrm{C}\right)$ by solid dissociation of zircon to zirconia and silica (Kaiser et al., 2008). Nevertheless, the temperature depends on impurities in the zircon crystals (such as rare earth elements (REE)), so that its dissociation can be expected to occur at substantially lower temperatures.

A study by Chumarev et al. (2008) showed that reduction of minerals with higher Ta content in respect to $\mathrm{Nb}$ and $\mathrm{Sn}$ happens at higher temperatures. As a reference, a wodginite with $70 \% \mathrm{Ta}_{2} \mathrm{O}_{5}$ and $\sim 10 \% \mathrm{SnO}_{2}$ reduces completely at $\sim 1450{ }^{\circ} \mathrm{C}$ (with formation of metallic tin within temperatures of $1200-1300^{\circ} \mathrm{C}$ ); a tantalite with $55 \% \mathrm{Ta}_{2} \mathrm{O}_{5}$ and $25 \% \mathrm{Nb}_{2} \mathrm{O}_{5}$ reduces at $\sim 1350^{\circ} \mathrm{C}$; and a columbite with $10 \% \mathrm{Ta}_{2} \mathrm{O}_{5}$ and $65 \% \mathrm{Nb}_{2} \mathrm{O}_{5}$ reduces at $\sim 1250{ }^{\circ} \mathrm{C}$. By analogy, the 
Table 5

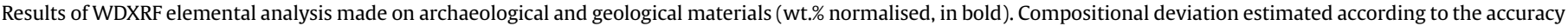
of the analysis (for $\mathrm{Zr}$ and $\mathrm{Ta}$ a relative error of $25 \%$ was assumed).

\begin{tabular}{|c|c|c|c|c|c|c|c|c|c|c|c|c|c|c|c|c|}
\hline \multicolumn{17}{|l|}{ A - Archaeological samples } \\
\hline Iron Slag A-Fe & n.d. & $\begin{array}{l}\mathbf{6 . 2} \\
0.99\end{array}$ & $\begin{array}{l}\mathbf{1 0 . 5} \\
2.10\end{array}$ & $\begin{array}{l}3.1 \\
0.25\end{array}$ & $\begin{array}{l}\mathbf{1 . 1} \\
0.23\end{array}$ & $\begin{array}{l}\mathbf{0 . 1} \\
0.03\end{array}$ & $\begin{array}{l}\mathbf{0 . 1 2} \\
0.03\end{array}$ & $\begin{array}{l}\mathbf{0 . 1 4} \\
0.02\end{array}$ & $\begin{array}{l}78.4 \\
35.3\end{array}$ & n.d. & n.d. & n.d. & n.d. & n.d. & n.d. & \\
\hline \multicolumn{17}{|l|}{ Ceramics } \\
\hline A-C1 & $\begin{array}{l}\mathbf{1 . 1 0} \\
0.50\end{array}$ & $\begin{array}{l}21.5 \\
3.44\end{array}$ & $\begin{array}{l}\mathbf{5 8 . 0} \\
11.6\end{array}$ & $\begin{array}{l}\mathbf{0 . 3 8} \\
0.03\end{array}$ & $\begin{array}{l}\mathbf{6 . 1} \\
1.28\end{array}$ & $\begin{array}{l}\mathbf{0 . 6 1} \\
0.15\end{array}$ & $\begin{array}{l}\mathbf{0 . 8 1} \\
0.17\end{array}$ & $\begin{array}{l}\mathbf{0 . 1 3} \\
0.02\end{array}$ & $\begin{array}{l}\mathbf{1 0 . 1 5} \\
4.57\end{array}$ & n.d. & $\begin{array}{l}\mathbf{0 . 0 2} \\
0.005\end{array}$ & n.d. & n.d. & n.d. & n.d. & $<2 \% \mathrm{NaO}$ \\
\hline A-C2b - black side & $\begin{array}{l}\mathbf{0 . 5 9} \\
0.27\end{array}$ & $\begin{array}{l}\mathbf{1 9 . 8} \\
3.17\end{array}$ & $\begin{array}{l}\mathbf{6 0 . 4} \\
12.1\end{array}$ & n.d. & $\begin{array}{l}\mathbf{5 . 5 0} \\
1.16\end{array}$ & n.d. & $\begin{array}{l}\mathbf{0 . 8 0} \\
0.17\end{array}$ & $\begin{array}{l}\mathbf{0 . 0 7} \\
0.01\end{array}$ & $\begin{array}{l}12.5 \\
5.6\end{array}$ & n.d. & $\begin{array}{l}\mathbf{0 . 0 1} \\
0.003\end{array}$ & $\begin{array}{l}\mathbf{0 . 0 3} \\
0.01\end{array}$ & $\begin{array}{l}\mathbf{0 . 2} \\
0.03\end{array}$ & n.d. & n.d. & \\
\hline A-C2r - red side & $\begin{array}{l}\mathbf{0 . 9 8} \\
0.44\end{array}$ & $\begin{array}{l}25.7 \\
4.1\end{array}$ & $\begin{array}{l}\mathbf{6 3 . 4} \\
12.7\end{array}$ & n.d. & $\begin{array}{l}4.3 \\
0.9\end{array}$ & n.d. & $\begin{array}{l}\mathbf{0 . 6} \\
0.13\end{array}$ & n.d. & $\begin{array}{l}4.1 \\
1.85\end{array}$ & n.d. & n.d. & n.d. & $\begin{array}{l}\mathbf{0 . 9 1} \\
0.12\end{array}$ & n.d. & n.d. & \\
\hline Tin slags & & & & & & & & & & & & & & & & \\
\hline A-S1 (sample 1) & $\begin{array}{l}\mathbf{0 . 7 0} \\
0.32\end{array}$ & $\begin{array}{l}\mathbf{1 3 . 4} \\
2.14\end{array}$ & $\begin{array}{l}\mathbf{3 6 . 8} \\
7.36\end{array}$ & $\begin{array}{l}\mathbf{0 . 4 6} \\
0.04\end{array}$ & $\begin{array}{l}2.50 \\
0.53\end{array}$ & $\begin{array}{l}0.7 \\
0.18\end{array}$ & $\begin{array}{l}\mathbf{6 . 6} \\
1.39\end{array}$ & $\begin{array}{l}2.4 \\
0.41\end{array}$ & $\begin{array}{l}\mathbf{1 4 . 6} \\
6.57\end{array}$ & n.d. & $\begin{array}{l}\mathbf{0 . 2 4} \\
0.06\end{array}$ & $\begin{array}{l}\mathbf{3 . 6} \\
0.90\end{array}$ & $\begin{array}{l}3.9 \\
0.51\end{array}$ & $\begin{array}{l}11.5 \\
2.88\end{array}$ & $\begin{array}{l}\mathbf{1 . 3} \\
0.07\end{array}$ & $<1 \% \mathrm{NaO}$ \\
\hline A-S1 (sample 2) & $\begin{array}{l}\mathbf{0 . 4 1} \\
0.18\end{array}$ & $\begin{array}{l}\mathbf{9 . 8 4} \\
1.57\end{array}$ & $\begin{array}{l}29.2 \\
5.84\end{array}$ & $\begin{array}{l}\mathbf{0 . 1 2} \\
0.01\end{array}$ & $\begin{array}{l}\mathbf{2 . 1 6} \\
0.45\end{array}$ & $\begin{array}{l}\mathbf{0 . 5 0} \\
0.13\end{array}$ & $\begin{array}{l}6.95 \\
1.46\end{array}$ & $\begin{array}{l}3.04 \\
0.52\end{array}$ & $\begin{array}{l}\mathbf{1 8 . 0} \\
8.1\end{array}$ & n.d. & $\begin{array}{l}0.37 \\
0.09\end{array}$ & $\begin{array}{l}\mathbf{5 . 9 5} \\
1.49\end{array}$ & $\begin{array}{l}7.60 \\
0.99\end{array}$ & $\begin{array}{l}13.7 \\
3.43\end{array}$ & $\begin{array}{l}\mathbf{2 . 0 1} \\
0.10\end{array}$ & Vestiges of Ce \\
\hline A-S2 (sample 1) & $\begin{array}{l}\mathbf{0 . 4 8} \\
0.22\end{array}$ & $\begin{array}{l}\mathbf{9 . 5 0} \\
1.52\end{array}$ & $\begin{array}{l}\mathbf{2 5 . 9} \\
5.18\end{array}$ & $\begin{array}{l}\mathbf{0 . 4 4} \\
0.04\end{array}$ & $\begin{array}{l}2.30 \\
0.48\end{array}$ & $\begin{array}{l}\mathbf{0 . 5 8} \\
0.15\end{array}$ & $\begin{array}{l}\mathbf{6 . 0 0} \\
1.26\end{array}$ & $\begin{array}{l}\mathbf{2 . 5 0} \\
0.43\end{array}$ & $\begin{array}{l}\mathbf{1 6 . 5} \\
7.43\end{array}$ & n.d. & $\begin{array}{l}\mathbf{0 . 4 6} \\
0.12\end{array}$ & $\begin{array}{l}7.40 \\
1.85\end{array}$ & $\begin{array}{l}\mathbf{1 4 . 6} \\
1.90\end{array}$ & $\begin{array}{l}\mathbf{1 1 . 6} \\
2.90\end{array}$ & $\begin{array}{l}\mathbf{1 . 6 0} \\
0.08\end{array}$ & \\
\hline A-S2 (sample 2) & $\begin{array}{l}\mathbf{0 . 2 3} \\
0.10\end{array}$ & $\begin{array}{l}\mathbf{8 . 1 1} \\
1.30\end{array}$ & $\begin{array}{l}23.9 \\
4.78\end{array}$ & $\begin{array}{l}\mathbf{0 . 0 6} \\
0.005\end{array}$ & $\begin{array}{l}\mathbf{1 . 8 6} \\
0.39\end{array}$ & $\begin{array}{l}\mathbf{0 . 6 1} \\
0.15\end{array}$ & $\begin{array}{l}\mathbf{5 . 9 1} \\
1.24\end{array}$ & $\begin{array}{l}2.70 \\
0.46\end{array}$ & $\begin{array}{l}\mathbf{1 8 . 2} \\
8.2\end{array}$ & n.d. & $\begin{array}{l}\mathbf{0 . 4 8} \\
0.12\end{array}$ & $\begin{array}{l}\mathbf{5 . 5 9} \\
1.4\end{array}$ & $\begin{array}{l}\mathbf{1 7 . 0} \\
2.2\end{array}$ & $\begin{array}{l}13.5 \\
3.4\end{array}$ & $\begin{array}{l}\mathbf{1 . 6 9} \\
0.08\end{array}$ & Vestiges of Y, Ce, Nd \\
\hline A-S3 (sample 1) & $\begin{array}{l}\mathbf{0 . 3 9} \\
0.18\end{array}$ & $\begin{array}{l}7.80 \\
1.25\end{array}$ & $\begin{array}{l}\mathbf{2 0 . 2} \\
4.04\end{array}$ & $\begin{array}{l}\mathbf{0 . 2 8} \\
0.02\end{array}$ & $\begin{array}{l}\mathbf{1 . 7} \\
0.36\end{array}$ & $\begin{array}{l}\mathbf{0 . 4 5} \\
0.11\end{array}$ & $\begin{array}{l}\mathbf{6 . 5} \\
1.37\end{array}$ & $\begin{array}{l}\mathbf{2 . 3} \\
0.39\end{array}$ & $\begin{array}{l}\mathbf{1 5 . 3} \\
6.89\end{array}$ & n.d. & $\begin{array}{l}\mathbf{0 . 4 7} \\
0.12\end{array}$ & $\begin{array}{l}\mathbf{8 . 1 0} \\
2.03\end{array}$ & $\begin{array}{l}23.4 \\
3.04\end{array}$ & $\begin{array}{l}\mathbf{1 1 . 5} \\
2.88\end{array}$ & $\begin{array}{l}\mathbf{1 . 5 0} \\
0.08\end{array}$ & \\
\hline A-S3 (sample 2) & $\begin{array}{l}\mathbf{0 . 2 4} \\
0.11\end{array}$ & $\begin{array}{l}7.15 \\
1.14\end{array}$ & $\begin{array}{l}19.0 \\
3.80\end{array}$ & $\begin{array}{l}\mathbf{0 . 1 0} \\
0.01\end{array}$ & $\begin{array}{l}1.46 \\
0.31\end{array}$ & $\begin{array}{l}\mathbf{0 . 6 5} \\
0.16\end{array}$ & $\begin{array}{l}5.96 \\
1.25\end{array}$ & $\begin{array}{l}2.52 \\
0.43\end{array}$ & $\begin{array}{l}\mathbf{1 5 . 9} \\
7.16\end{array}$ & n.d. & $\begin{array}{l}\mathbf{0 . 4 6} \\
0.12\end{array}$ & $\begin{array}{l}\mathbf{8 . 1 9} \\
2.05\end{array}$ & $\begin{array}{l}24.4 \\
3.17\end{array}$ & $\begin{array}{l}12.2 \\
3.05\end{array}$ & $\begin{array}{l}\mathbf{1 . 5 6} \\
0.08\end{array}$ & Vestiges of Ce, $\mathrm{Hf}$ \\
\hline C - Cassiterite samples & & & & & & & & & & & & & & & & \\
\hline C3 “Ancient exploitation” & n.d. & $\begin{array}{l}\mathbf{4 . 0} \\
0.64\end{array}$ & $\begin{array}{l}\mathbf{9 . 6} \\
1.92\end{array}$ & n.d. & $\begin{array}{l}\mathbf{0 . 2 8} \\
0.06\end{array}$ & $\begin{array}{l}\mathbf{0 . 1 7} \\
0.04\end{array}$ & $\begin{array}{l}1.40 \\
0.29\end{array}$ & n.d. & $\begin{array}{l}\mathbf{1 2 . 3} \\
5.51\end{array}$ & $\begin{array}{l}\mathbf{9 . 3} \\
3.35\end{array}$ & n.d. & $\begin{array}{l}2.3 \\
0.6\end{array}$ & $\begin{array}{l}\mathbf{6 0 . 7} \\
7.9\end{array}$ & n.d. & n.d. & \\
\hline C2 Ribeira das Lameiras (two cassiterite grains) & n.d. & $\begin{array}{l}12.7 \\
2.03\end{array}$ & $\begin{array}{l}31.2 \\
6.24\end{array}$ & n.d. & $\begin{array}{l}\mathbf{1 . 8} \\
0.38\end{array}$ & n.d. & $\begin{array}{l}7.4 \\
1.55\end{array}$ & $\begin{array}{l}\mathbf{3 . 0} \\
0.51\end{array}$ & $\begin{array}{l}\mathbf{9 . 4} \\
4.23\end{array}$ & n.d. & $\begin{array}{l}\mathbf{0 . 1} \\
0.03\end{array}$ & $\begin{array}{l}4.2 \\
1.05\end{array}$ & $\begin{array}{l}\mathbf{2 6 . 7} \\
3.47\end{array}$ & $\begin{array}{l}\mathbf{2 . 8} \\
0.70\end{array}$ & $\begin{array}{l}\mathbf{0 . 6 3} \\
0.03\end{array}$ & \\
\hline C5 Gondiães (sample 1 less gangue) & n.d. & $\begin{array}{l}\mathbf{1 8 . 0} \\
2.88\end{array}$ & $\begin{array}{l}\mathbf{2 1 . 0} \\
4.2\end{array}$ & n.d. & $\begin{array}{l}\mathbf{1 . 9 0} \\
0.40\end{array}$ & $\begin{array}{l}\mathbf{0 . 3 6} \\
0.09\end{array}$ & $\begin{array}{l}\mathbf{0 . 0 7} \\
0.01\end{array}$ & $\begin{array}{l}\mathbf{0 . 0 7 1} \\
0.01\end{array}$ & $\begin{array}{l}\mathbf{0 . 6 9} \\
0.3\end{array}$ & n.d. & $\begin{array}{l}\mathbf{0 . 0 5} \\
0.01\end{array}$ & $\begin{array}{l}\mathbf{0 . 6 6} \\
0.17\end{array}$ & $\begin{array}{l}\mathbf{5 4 . 0} \\
7.0\end{array}$ & $\begin{array}{l}\mathbf{1 . 1 0} \\
0.28\end{array}$ & n.d. & \\
\hline C5 Gondiães (sample 2 more gangue) & n.d. & $\begin{array}{l}20.8 \\
3.33\end{array}$ & $\begin{array}{l}\mathbf{3 4 . 8} \\
6.96\end{array}$ & n.d. & $\begin{array}{l}\mathbf{1 . 9 4} \\
0.41\end{array}$ & n.d. & $\begin{array}{l}\mathbf{0 . 1 0} \\
0.02\end{array}$ & n.d. & $\begin{array}{l}\mathbf{0 . 5 2} \\
0.23\end{array}$ & n.d. & $\begin{array}{l}\mathbf{0 . 0 3} \\
0.01\end{array}$ & $\begin{array}{l}\mathbf{0 . 5 4 2} \\
0.14\end{array}$ & $\begin{array}{l}36.1 \\
4.69\end{array}$ & $\begin{array}{l}\mathbf{0 . 9 7} \\
0.24\end{array}$ & n.d. & \\
\hline
\end{tabular}

tapiolite and columbite minerals found in the slag (with $70 \%$ and $50 \% \mathrm{Ta}_{2} \mathrm{O}_{5}$ ) would represent those with the highest Ta contents originally present in the smelt. Consequently, most of the minerals in the original ore concentrate would have smaller Ta contents, and would have decomposed at temperatures $<\sim 1350^{\circ} \mathrm{C}$.

The XRD patterns of the three tin slags provide very similar results. All can be explained based on a combination of $\mathrm{TaO}_{2}$, $\mathrm{FeTaO}_{4}, \mathrm{FeNbO}_{4}, \mathrm{FeNb}_{2} \mathrm{O}_{6}$ and $\mathrm{MnTiO}_{3}$ crystal structures (Fig. 8). From these, $\mathrm{TaO}_{2}$ clearly points out to a reducing atmosphere in the metallurgical operation.

Past studies about phase transformation during metal reduction of natural iron-manganese tantalum niobates with carbon when heating to high temperatures (generally $>1400^{\circ} \mathrm{C}$ ) have shown that intermediary products are suboxides $\left(\mathrm{MO}_{2}\right)$ and final products are oxycarbides (MCx(MCxOy)) (Chumarev et al., 2008; Terry et al., 1994).

Generally, based on the slag's microstructure one can suppose that smelting temperatures could have been higher than $1200-1250^{\circ} \mathrm{C}$ to allow the decomposition of most of the Tacontaining minerals and allow the formation of three phase SnW-Fe metallic globules, but lower than $\sim 1400^{\circ} \mathrm{C}$ since very rich Ta minerals only decomposed partially, and the final crystal phases formed are predominately oxides and not oxycarbides.

When compared to other European ancient tin slags, the size, colour, composition and microstructure of the Carvalhelhos slags show closer similarities to the Centum Cellas slags (central Portugal) (Merideth, 1996). SEM-EDS area analysis of the Centum Cellas slags showed that the tin content was generally high but could vary between 2 and $20 \% \mathrm{SnO}_{2}$ while relatively high contents of $\mathrm{Nb}$ and Ta were always present $\left(6-14 \% \mathrm{Nb}_{2} \mathrm{O}_{5}\right.$ and $\left.9-12 \% \mathrm{Ta}_{2} \mathrm{O}_{5}\right)$. Other elements were $\mathrm{Fe}$, $\mathrm{Ti}$ and $\mathrm{Mn}\left(25-30 \% \mathrm{Fe}_{2} \mathrm{O}_{3}, 8-16 \% \mathrm{TiO}_{2}\right.$ and $\sim 2 \% \mathrm{MnO}$ ). The microstructural studies showed that there was a primary Ta-rich phase and another Fe-Mn-rich phase while Sn remained mainly in the glassy matrix. The presence of small metallic Sn globules was also observed. Given that slag composition and microstructure are mostly influenced by the composition of the ores used (Malham, 2010), it can be assumed that the ores used at both sites must have been chemically relatively similar, as formed by $\mathrm{Ta}$ and $\mathrm{Nb}$ rich cassiterite concentrates.

\subsubsection{Cassiterites}

The WDXRF analyses and SEM-EDS made of the cassiterite samples collected from two secondary deposits (C1 and C2) (Table 5 and Fig. 9) and three primary deposits (C3, C4 and C5) (Table 5 and Fig. 10) allowed distinguishing among them based on the purity of the cassiterite crystal and on the presence of micro-inclusions (Table 2(b)). Complementary information of associated minerals of relevance for the interpretation of slags composition was also provided.

The cassiterite samples taken from the two secondary places (alluvial), C1 (Bessa, $4 \mathrm{~km} \mathrm{~N}$ Carvalhelhos) and C2 (Ribeira das Lameiras, Carvalhelhos), are very different. On the one hand, the cassiterite grains from Bessa are very pure, and only zircon inclusions (with Hf) were found. On the other hand, the cassiterite grains from Ribeira das Lameiras showed relatively high amounts of $\mathrm{Ta}$ and $\mathrm{Nb}$ in their crystal structure. The associated minerals from both sites - that were present at the last stage of the panning and of dark colour - showed the presence of a cyclosilicate, possibly beryl, with micro-inclusions of monazite ((Ce,La,Nd,Th) $\left.\mathrm{PO}_{4}\right)$ and zircon (without $\mathrm{Hf}$ ). In the case of the $\mathrm{C} 1$ sample (Bessa), a relatively large crystal of Fe-columbite was also found; a rutile $\left(\mathrm{TiO}_{2}\right)$ crystal with needle-shaped cassiterite crystals on the surface; and a silicate 

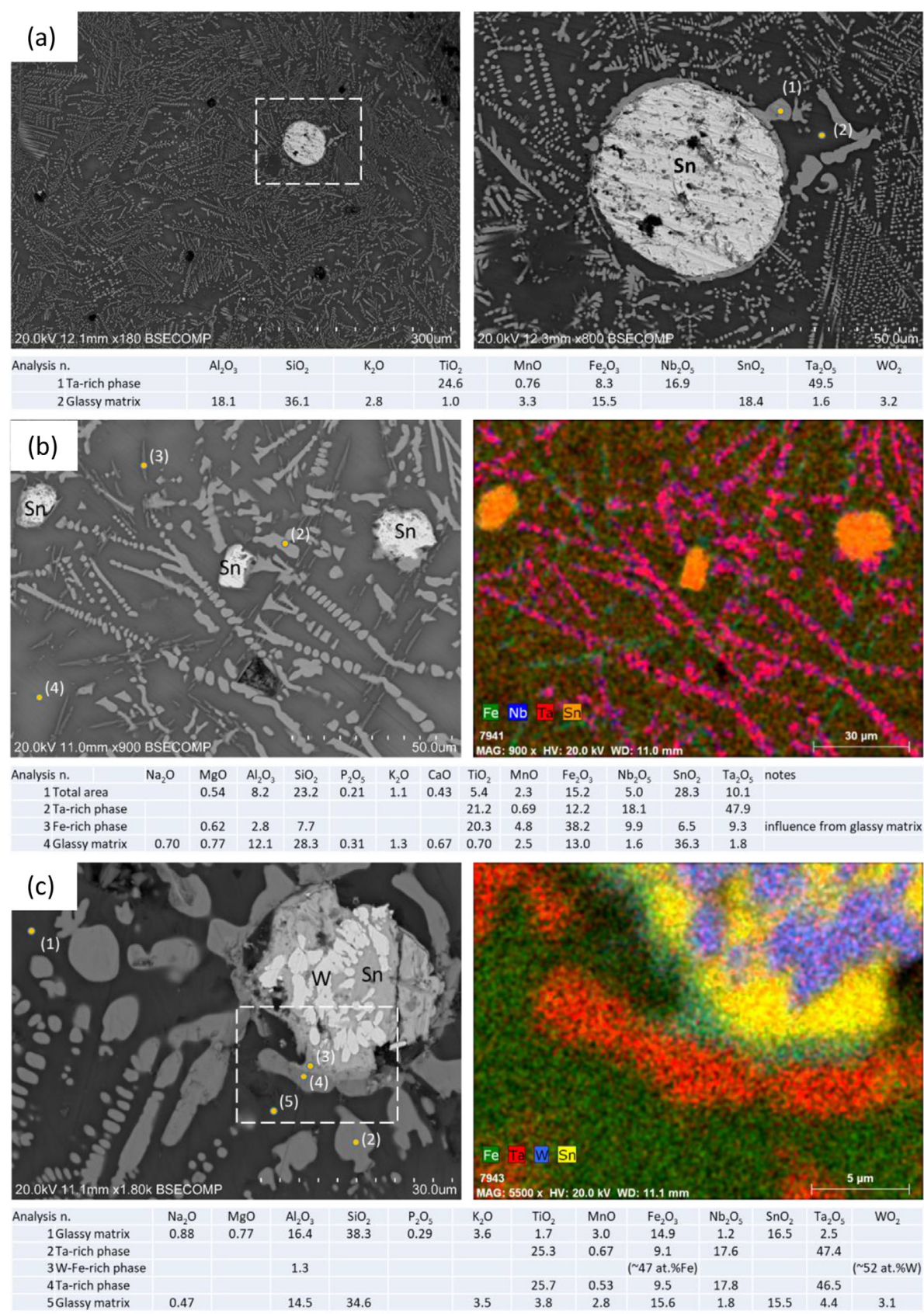

Fig. 5. SEM (BSE) images and EDS analysis of the three tin slags at type I regions: (a) tin slag (A-S1) microstructure composed by long Ta-rich dendrites and Sn globules (a relatively large globule is shown in the image) among a glassy matrix. Results of EDS analysis to Ta-rich phase and glassy matrix at the bottom; (b) tin slag (A-S3) at a region with a secondary phase Fe-rich, besides the Ta-rich dendrites and Sn metallic globules, in a glassy matrix. At the right EDS elemental mapping and at bottom EDS chemical composition of total area or point analyses of different microconstituents; (c) tin slag (A-S2) showing a metallic globule constituted by three phases: W-metal, Sn-metal and W-Fe-metal (chemical formula close to Fe7W6). Elemental mapping is shown at the right and chemical composition by EDS point analyses to different microconstituents is shown in a table at the bottom.

mineral, probably topaz, with ilmenite $\left(\mathrm{FeTiO}_{3}\right)$ inclusions. In the C2 sample (Ribeira das Lameiras), ilmenite with zircon (without $\mathrm{Hf}$ ) and monazite inclusions were also identified.

The three samples from the primary deposits did also show some differences among them. The C3 sample ("ancient exploitation", $2 \mathrm{~km}$ SW Carvalhelhos) evidenced very pure cassiterite crystals with various types of micro-inclusions, of which some were only found in this cassiterite sample. These were As-Bi rich inclusions, possibly minerals from the preisingerite group $\left(\mathrm{Bi}_{3}(\mathrm{~A}-\right.$ $\left.\left.\mathrm{SO}_{4}\right)_{2} \mathrm{O}(\mathrm{OH})\right)$ and wolframite $\left((\mathrm{Fe}, \mathrm{Mn}) \mathrm{WO}_{4}\right)$ inclusions. Other inclusions were columbite $\left((\mathrm{Fe}, \mathrm{Mn})(\mathrm{Nb}, \mathrm{Ta}) \mathrm{O}_{6}\right)$, rutile $\left(\mathrm{TiO}_{2}\right)$ and zoned Ti-Nb-rich crystals (exsolutions). Associated to the cassiterite was quartz and weathered arsenopyrite. The weathered products, besides Fe, As and $\mathrm{S}$ also incorporated relatively high levels of $\mathrm{P}$. Most likely these products are phosphoscorodite (Fe(As,P) $\mathrm{O}_{4} \cdot 2 \mathrm{H}_{2} \mathrm{O}$ ), commonly found in weathered arsenopyrites from abandoned W or Sn-mining sites (Murciego et al., 2011).

The cassiterite sample from Dornelas (9 km SW Carvalhelhos) showed cassiterite crystals with $\mathrm{Ta}, \mathrm{Nb}$ and $\mathrm{Fe}$, with a higher content of Ta than $\mathrm{Nb}\left(2.5-5 \% \mathrm{Ta}_{2} \mathrm{O}_{5},<1 \% \mathrm{Nb}_{2} \mathrm{O}_{5}\right.$ and $\left.<1 \% \mathrm{Fe}_{2} \mathrm{O}_{3}\right)$. Inclusions were of columbite, tapiolite and zircon (with $~ 10 \mathrm{wt} \% \mathrm{Hf}$ ), and many of the columbite inclusions were zoned (exsolutions). 

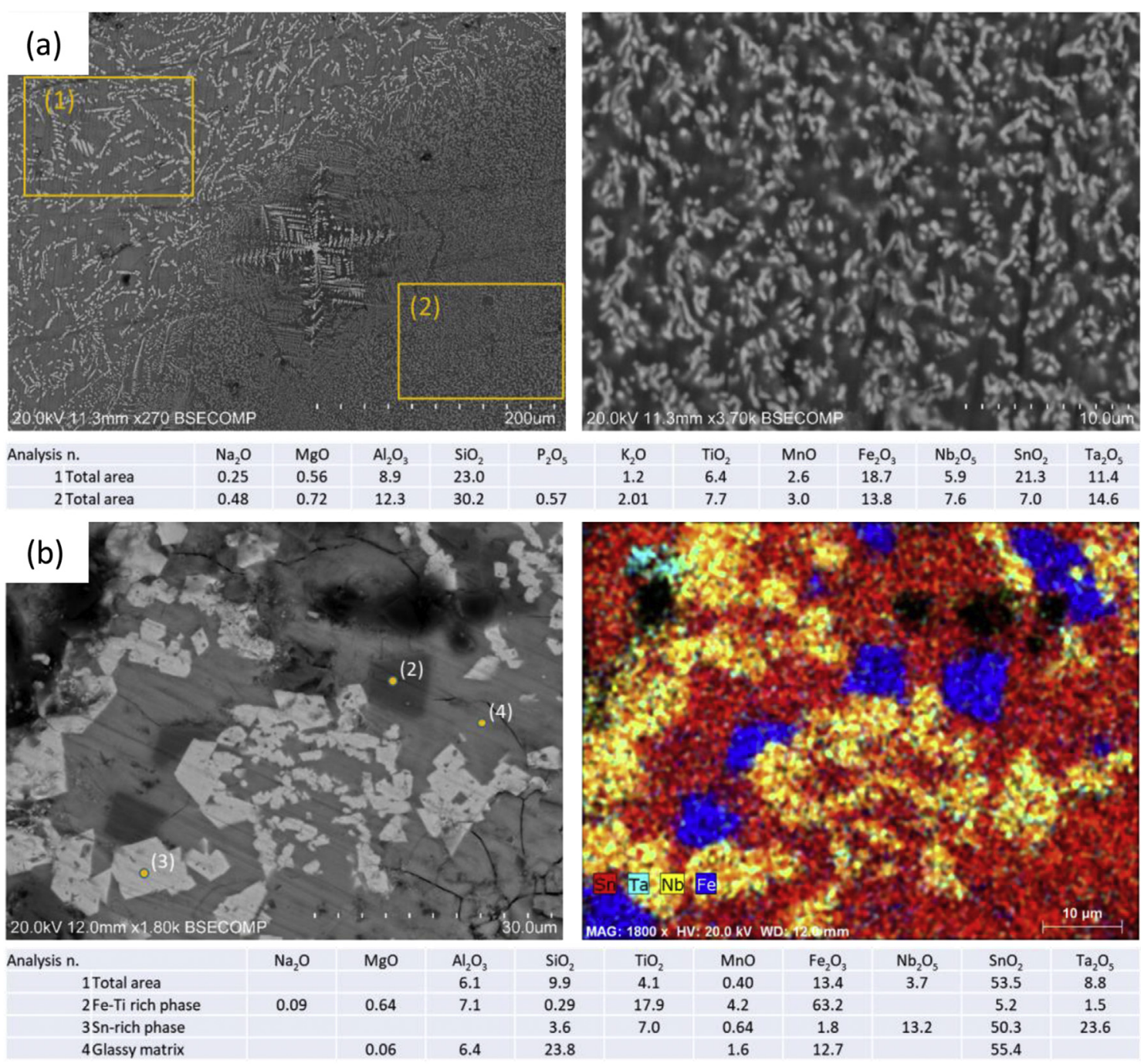

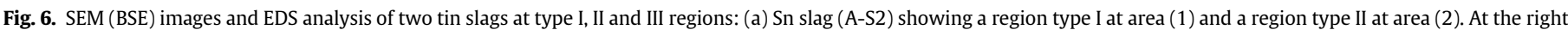

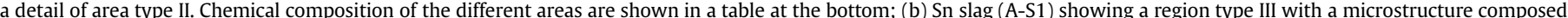
by Fe-Ti rich and Sn-rich phases in a glassy matrix. At right an elemental mapping and at the bottom chemical composition by EDS to different microconstituents.

The C4 sample (Gondiães, $13 \mathrm{~km}$ SW Carvalhelhos) showed cassiterite crystals with Ta and low amounts of $\mathrm{Nb}$ and $\mathrm{Fe}\left(3 \% \mathrm{Ta}_{2} \mathrm{O}_{5}\right.$, $<1 \% \mathrm{Nb}_{2} \mathrm{O}_{5}$ and $<1 \% \mathrm{Fe}_{2} \mathrm{O}_{3}$ ). Tantalum appeared to be heterogeneously distributed, resulting in zoning of the cassiterite crystals. Numerous inclusions of columbite with zoning (exsolutions) were also found. Associated minerals determined by XRD and SEM-EDS were quartz, albite and muscovite.

Based on the analysed cassiterite samples it appears that Ta and $\mathrm{Nb}$ in the slags can result from (1) the presence of these elements in cassiterite crystal (being that higher amounts of Ta are expected since some Ta oxide structures are cassiterite-like structures (Wise and Černŷ, 1996) so that Ta accommodates better in cassiterite crystal structure than $\mathrm{Nb}$ ) or from (2) the presence of minerals such as columbite, tantalite and tapiolite, as (2a) inclusions or as (2b) associated minerals, all of which seem to be frequent in the cassiterites from the region.

Also, the presence of monazite and zircon as associated minerals or inclusion (in the case of zircon) explains the presence of traces of $\mathrm{Ce}, \mathrm{Nd}$ and $\mathrm{Hf}$ in the slags. Moreover, in our case the presence of $\mathrm{Zr}$ in the slags cannot be associated with a preferential use of alluvial cassiterite sources instead of primary ones as proposed for other areas (Chirikure et al., 2010).
Since tin slags result from a mixture of cassiterite crystals, their inclusions and a random mixture of associated minerals, EDS area analysis and WDXRF analysis of slags and cassiterite samples were compared in ternary plots to search for signs on deliberate addition of fluxes. Although by using different analytical techniques, affinities or tendencies can become apparent.

The ternary plot with relative values of Ta, Nb and $\mathrm{W}$ (Fig. 11a) show that $\mathrm{Sn}$ slags have $\mathrm{Ta} / \mathrm{Nb}$ oxide ratios closer to many of the studied cassiterite samples and associated columbite group minerals than to the general composition of the streambed sediment samples of the region (Pires, 1995). This probably relates with different aims and sampling methods. In the geochemical study a granulometric separation of the sediments was made, being analysed the grain fraction of 80 mesh $(177 \mu \mathrm{m})$. In the present study an intentional collection of cassiterite grains was made, independently of the grain size, which probably corresponds better with ancient tin mining actions, resulting in a better fitting of the chemical signatures.

When Sn slags are compared to local cassiterites and columbite group minerals from our sample regarding their relative $\mathrm{Ta}, \mathrm{Nb}, \mathrm{Fe}$ and Ti contents (Fig. 11b and c) it is observed that the slags are located within the cassiterites composition. Nevertheless, it should 

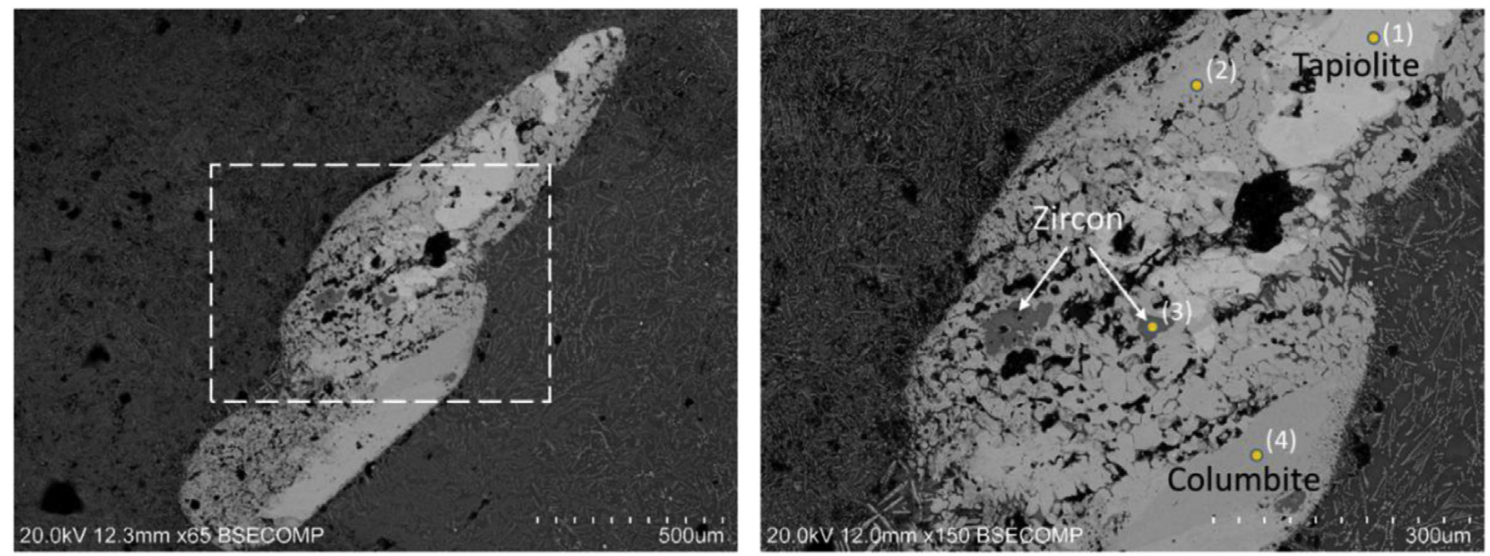

\begin{tabular}{|c|c|c|c|c|c|c|c|c|c|}
\hline Analysis $\mathrm{n}$. & $\mathrm{SiO}_{2}$ & $\mathrm{TiO}_{2}$ & $\mathrm{MnO}$ & $\mathrm{Fe}_{2} \mathrm{O}_{3}$ & $\mathrm{ZrO}_{2}$ & $\mathrm{Nb}_{2} \mathrm{O}_{5}$ & $\mathrm{HfO}_{2}$ & $\mathrm{Ta}_{2} \mathrm{O}_{5}$ & notes \\
\hline 1Tapiolite & & 1.7 & & 14.9 & & 6.5 & & 76.9 & \\
\hline 2 Altered minerals & 6.0 & 0.59 & 4.8 & 10.9 & & 21.3 & & 56.4 & \\
\hline 3Zircon inclusion & 29.0 & & & & 56.5 & & 14.5 & & Common accessory mineral \\
\hline 4 Columbite & & & 4.4 & 14.1 & & 30.7 & & 50.7 & \\
\hline
\end{tabular}

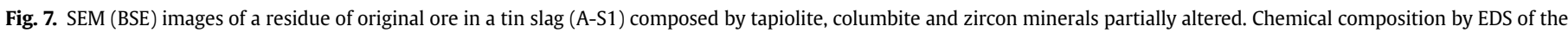
different microconstituents at the bottom.

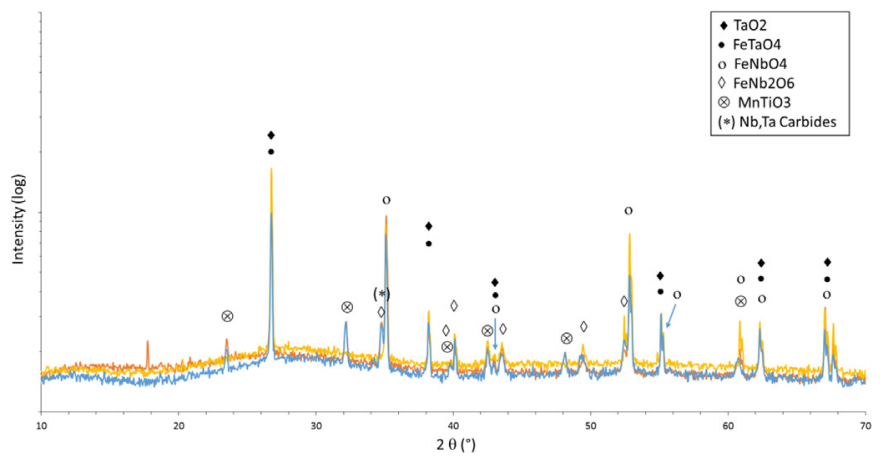

Fig. 8. XRD diffractograms of the three Sn slags studied. Results show crystal structures that can be interpreted as a combination of $\mathrm{TaO}_{2}, \mathrm{FeTaO}_{4}, \mathrm{FeNbO}_{4}, \mathrm{FeNb}_{2} \mathrm{O}_{6}$ and $\mathrm{MnTiO}_{3}$. One line that can be related to Ta or Nb carbides is also present.

be noted that the alluvial cassiterite samples from Ribeira das Lameiras are those that provide the highest $\mathrm{Fe}+\mathrm{Ti}$ content in relation to $\mathrm{Ta}+\mathrm{Nb}$, and are thus crucial to provide an adequate frame for the Carvalhelhos Sn slags. The Centum Cellas slags show compositions relatively similar to the Carvalhelhos slags, with only a small tendency for a lower relative amount of Ta.

The $\mathrm{Si}, \mathrm{Al}$ and Fe contents of the Sn slags were also compared to those present in the minerals that compose the pegmatites from the region: quartz, feldspar and muscovite (Fig. 11d). Mixture lines were drawn towards the Fe oxide vertice, which represent an element present in many other associated minerals, including cassiterite. It is shown that composition of Sn slags coincide practically with the mixture line of the feldspar with a Fe-bearing mineral, which is also between the quartz and the muscovite lines. This may indicate that all these three minerals could have entered equally into the smelt.

Finally, and based on the present results, we found no indication for an intentional addition of Fe oxides to the tin smelt as suggested by Maia e Costa (1966).

\subsection{Iron slag}

The WDXRF analysis of the iron slag shows that it contains $~ 80 \%$ $\mathrm{Fe}_{2} \mathrm{O}_{3}, \sim 10 \% \mathrm{SiO}_{2}, \sim 6 \% \mathrm{Al}_{2} \mathrm{O}_{3}, \sim 3 \% \mathrm{P}_{2} \mathrm{O}_{5}, \sim 1 \% \mathrm{~K}_{2} \mathrm{O}$ and $<1 \% \mathrm{CaO}, \mathrm{TiO}_{2}$ and $\mathrm{MnO}$ (Table 5). Given the high Fe content and absence of Sn, this material shows no relation to Sn metallurgy, but rather resembles a typical product of iron metallurgy. Comparing this material to the previous slag analysed by Maia e Costa (1966), some similarities can be found, including a relatively high Fe content $\left(\sim 65 \% \mathrm{Fe}_{2} \mathrm{O}_{3}\right)$, presence of $\mathrm{Si}$ and $\mathrm{Al}$ oxides ( $20 \%$ and $10 \%$, respectively) and presence of Ti, Mn and $\mathrm{P}$ in low amounts. The real difference between both slags appears to be the presence of small amounts of $\mathrm{Sn}\left(\sim 2 \% \mathrm{SnO}_{2}\right)$ in the slag discussed by Maia e Costa (1966).

The SEM-EDS analysis of the present slag (Fig. 12) showed that it contains small amounts of metallic iron and wustite surrounded by large amounts of fayalite, and many alteration products (corrosion undergone during burial). The metallic iron is present as particles up to $50 \mu \mathrm{m}$, but larger particles appear to have existed that were severely affected by corrosion. Particles of wustite often appear to be dendritic, indicative of a primary solid phase. Islands of a eutectic structure, leucite $\left(\mathrm{KAlSi}_{2} \mathrm{O}_{6}\right)$, are frequent, and these are also commonly observed on Fe slags (Friede et al., 1982; Soulignac, 2017). Elemental mapping of these particles revealed a discontinuous phase of wustite surrounded by more than one phase with compositional variations in $\mathrm{Al}, \mathrm{K}, \mathrm{Si}$ or P elements (Fig. 12).

The XRD pattern of a powder sample shows the presence of Fe oxide-hydroxides corrosion products, such as lepidocrocite $(\gamma$ $\mathrm{FeO}(\mathrm{OH})$ ), and reveals the presence of quartz $\left(\mathrm{SiO}_{2}\right)$, fayalite $\left(\mathrm{Fe}_{2} \mathrm{SiO}_{4}\right)$, magnetite $\left(\mathrm{Fe}_{3} \mathrm{O}_{4}\right)$ and possibly wustite $(\mathrm{FeO})$ and goethite $(\alpha-\mathrm{FeO}(\mathrm{OH}))$. The micro-XRD pattern of the small polished area observed in SEM-EDS shows fayalite. This indicates, as did the SEM images, that fayalite make up most of the analysed area of the slag.

Interpreting the slag in terms of local metallurgy is challenging, since systematic studies of Fe-slags from the site are absent, and it is difficult to distinguish among iron smelting or smithing slags 

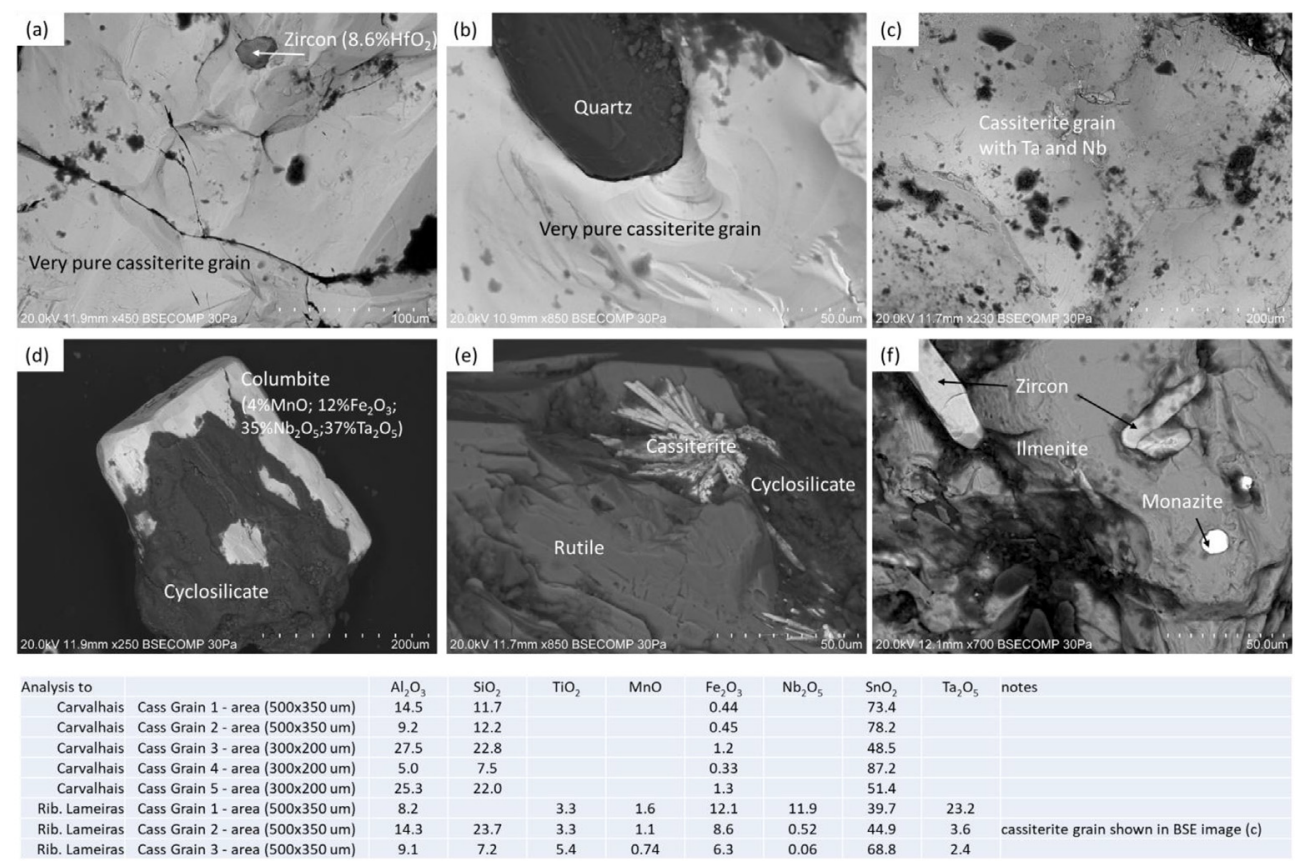

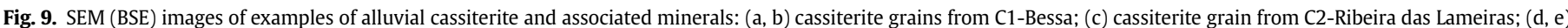

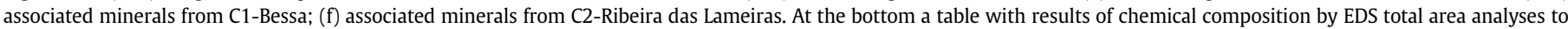
cassiterite grains is shown.

based only on their composition and microstructure. Both can show the same type of composition and phases (Selskiene, 2007) and even smithing slags can show significant variations based on aspect, mineralogical and chemical composition (Serneels and Perret, 2003). Possibly, future studies can focus in the iron metallurgy of the site by studding a large sample of slags. Still, the present slag shows that besides tin metallurgy, iron metallurgy was also performed at the site.

\subsection{Ceramics}

The WDXRF elemental analyses of the two ceramic fragments (A-C1 and A-C2) show that they have similar chemical compositions (Table 5). They consist on $58-63 \% \mathrm{SiO}_{2}, 20-25 \% \mathrm{Al}_{2} \mathrm{O}_{3}, 4-12 \%$ $\mathrm{Fe}_{2} \mathrm{O}_{3}$ and $4-6 \% \mathrm{~K}_{2} \mathrm{O}$ with some smaller amounts of $\sim 1 \% \mathrm{MgO}$ and $<1 \% \mathrm{TiO}_{2}$ and $\mathrm{MnO}$. The very low amount or absence of $\mathrm{CaO}$ indicates the use of non-calcareous clays and the relatively high potash contents $\left(4-6 \% \mathrm{~K}_{2} \mathrm{O}\right.$ ) points to the presence of clay minerals such as illite.

Beside the presence of elements related to the ceramic material other elements were detected that can be related to Sn metallurgy. Small amounts of $\mathrm{Sn}\left(<1 \% \mathrm{SnO}_{2}\right)$ were detected in the ceramic A$\mathrm{C} 2 \mathrm{~b}$ and $\mathrm{A}-\mathrm{C} 2 \mathrm{r}$, and $\mathrm{Nb}$ was detected in $\mathrm{A}-\mathrm{C} 2 \mathrm{~b}\left(0.03 \% \mathrm{Nb}_{2} \mathrm{O}_{5}\right)$. The presence of these elements in small amounts could suggest that these fragments were part of a metallurgical structure, as for example a furnace wall or lining. Sn-rich vapours can easily be released from silicate melts (Debroy et al., 1990), resulting in the reaction and incorporation of this element in other structure materials. This would mean that beside tin slags, during the old archaeological works also refractory materials were collected.

The XRD analysis made on the two samples from Carvalhelhos, in powder and micro-XRD modes, show different but complementary diffraction patterns on both sides of the ceramics (Fig. 13).

Sample A-C1, in the grey and powdery textured side has strong quartz $\left(\mathrm{SiO}_{2}\right)$ and $\mathrm{K}$-feldspar $\left(\mathrm{KAlSi}_{3} \mathrm{O}_{8}\right)$ crystal patterns, besides mullite $\left(\mathrm{Al}_{6} \mathrm{Si}_{2} \mathrm{O}_{13}\right)$ and hematite $\left(\mathrm{Fe}_{2} \mathrm{O}_{3}\right.$, $\left.\mathrm{Fe}[\mathrm{III}]\right)$. The black and hard side shows mainly a maghemite $\left(\gamma-\mathrm{Fe}_{2} \mathrm{O}_{3}, \mathrm{Fe}[\mathrm{III}]\right.$-deficient) crystal structure. Maghemite can be formed as a low temperature oxidation product of magnetite (Kapper et al., 2014), and indicates that this ceramic side was subjected to a reducing atmosphere. In the diffraction pattern of the bulk mixture that includes both sides (powder XRD), cristobalite was found, together with a stronger signal of mullite and absence of feldspar. From these, mullite is rarely found in nature, and is a common product in man-made ceramics. It is considered as a refractory material due to its high melting point $\left(>1800^{\circ} \mathrm{C}\right)$ and it is the only stable intermediate phase in the $\mathrm{Al}_{2} \mathrm{O}_{3}-\mathrm{SiO}_{2}$ system at atmospheric pressure (Duval et al., 2008). In studies of fired non-calcareous ceramics composed of mixtures of kaolinitic and illitic clays with large quartz contents, mullite and cristobalite began to be formed at $1000-1100^{\circ} \mathrm{C}$ and become more abundant at higher temperatures (Trindade et al., 2010; El Ouahabi et al., 2015).

In the present sample, the presence of a well-developed mullite crystalline pattern with the formation of cristobalite indicates that this ceramic must have been exposed to temperatures above $1100^{\circ} \mathrm{C}$, possibly $\sim 1200^{\circ} \mathrm{C}$.

In the sample $\mathrm{A}-\mathrm{C} 2$, quartz and hercynite $\left(\mathrm{FeAl}_{2} \mathrm{O}_{4}, \mathrm{Fe}[\mathrm{II}]\right)$ were found on the blackish side (micro-XRD), together with some mullite, hematite and k-feldspar (powder XRD). On the reddish side, quartz and hematite were detected at the surface (micro-XRD) and hercynite was also found in the powder analysis (although this can result from some contamination by the black zone). In this case, the black area clearly was subjected to reducing conditions.

Analyses of pyrometallurgical structures of the same period as Carvalhelhos hillfort are rare. Bulk analyses of silver-smelting furnace walls from Rio Tinto (Southern Iberian Peninsula) from the 1 st to 2 nd century BCE revealed a chemical composition of $65-71 \% \mathrm{SiO}_{2}, 18-20 \% \mathrm{Al}_{2} \mathrm{O}_{3}, 3-7 \% \mathrm{FeO} ; 4-6 \mathrm{~K}_{2} \mathrm{O}, 1-2 \mathrm{MgO}$ and $\sim 1 \%$ $\mathrm{TiO}_{2}$, not so different from the Carvalhelhos fragments. Experimental refiring tests of these furnace walls suggested that they were subjected to temperatures of $1200^{\circ} \mathrm{C}$ for approximately ten hours (Freestone and Tite, 1986), revealing the adequacy of this 

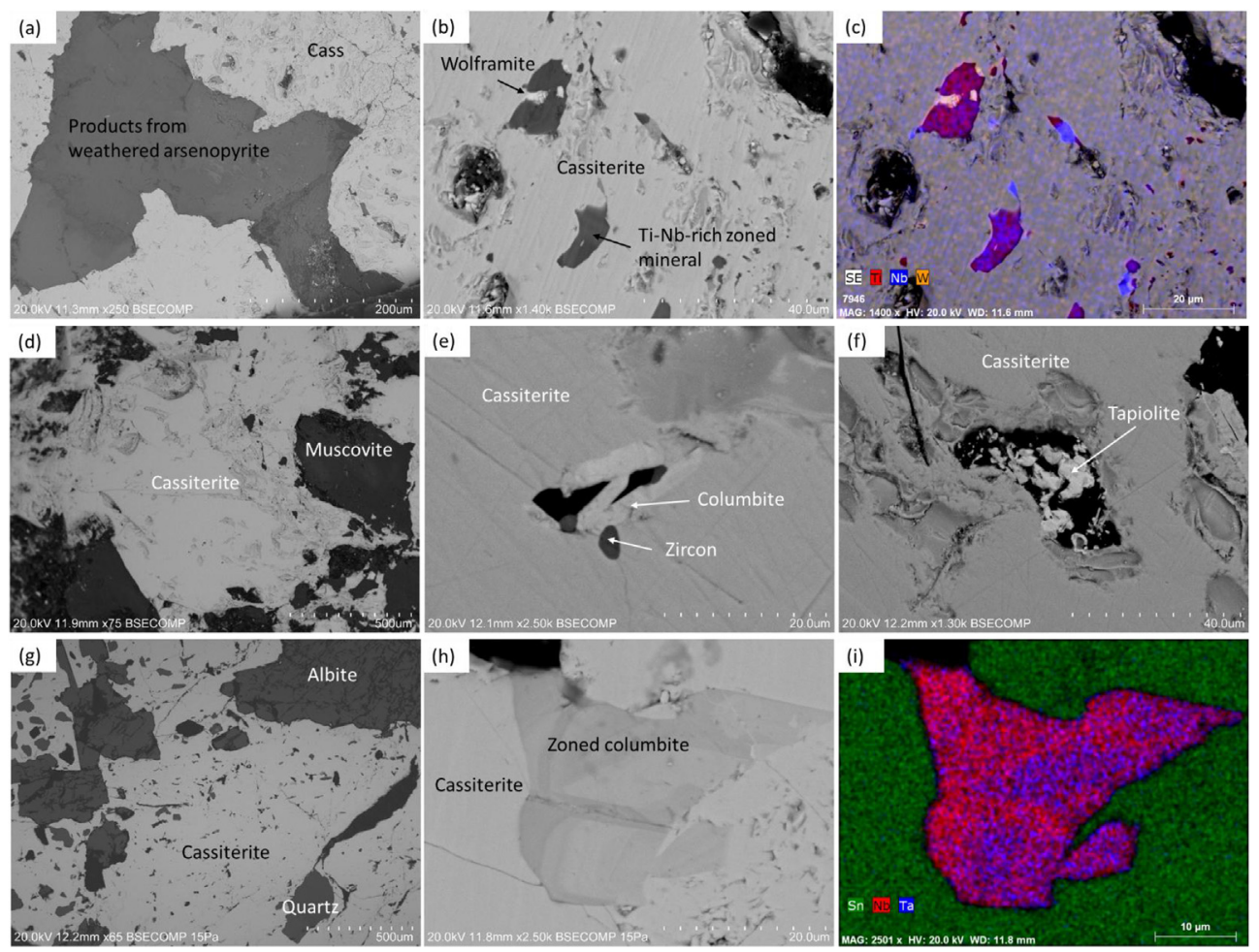

Analysis to "Ancient Exploitation"

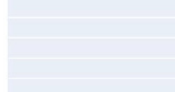

Dornelas

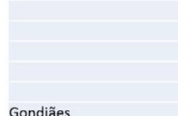

Gondiães
Cassiterite EDS total area $\mathrm{Nb}-\mathrm{W}$-Fe-rich inclusio Wolframite
Rulite-like inclusi Weathered arsenopyrite EDS total area
Cassiterite Cassiterite
Columbite Cassiterite EDS total area Tapiolite
Cassiterite
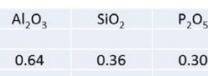

$0.36 \quad 0.30$
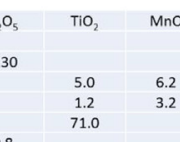

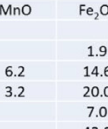

\begin{tabular}{|c|c|c|c|c|c|}
\hline $\mathrm{Fe}_{2} \mathrm{O}_{3}$ & $\mathrm{As}_{2} \mathrm{O}_{3}$ & $\mathrm{Nb}_{2} \mathrm{O}_{5}$ & $\begin{array}{c}\mathrm{SnO}_{2} \\
100\end{array}$ & $\mathrm{Ta}_{2} \mathrm{O}_{5}$ & $\mathrm{WO}_{2}$ \\
\hline 1.9 & 2.1 & & 94.8 & & \\
\hline 14.6 & & 44.1 & 4.0 & 5.5 & 20.4 \\
\hline 20.0 & & 1.8 & & & 73.9 \\
\hline 7.0 & & 13.4 & 2.2 & 6.5 & \\
\hline 43.8 & 55.4 & & & & \\
\hline 0.63 & & & 81.0 & 2.6 & \\
\hline 0.90 & & 0.73 & 93.7 & 4.7 & \\
11.7 & & 22.9 & & 61.0 & \\
0.66 & & 0.22 & 95.2 & 3.9 & \\
0.80 & & 0.34 & 94.0 & 4.9 & \\
\hline 15.1 & & 4.3 & & 80.3 & \\
\hline 0.53 & & 0.63 & 95.7 & 3.2 & \\
\hline
\end{tabular}

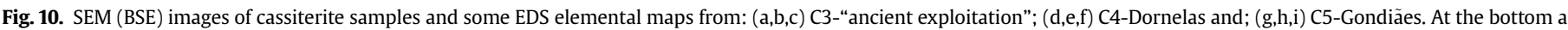
table with results of chemical composition by EDS

type of material for pyrometallurgical operations.

\subsection{Some final discussion}

The Sn slag fragments are of relatively large size, if compared to the few Pre-Roman Sn slags found elsewhere, and of comparable size and composition to the ones found in Centum Cellas Roman site (central Portugal). The Sn slag's composition is consistent with the smelting of local/Iberian cassiterite ores and results suggest that there was no need for intentional addition of fluxes, especially if associated geological materials also entered in the smelting process due to an incomplete/not careful separation of ore and gangue. Smelters could have seen practical advantages in not making a very careful ore beneficiation: besides reducing the time of ore concentration, the smelting could be facilitated due to the production of a silica-alumina slag where all the impurities of the cassiterite (namely $\mathrm{Ta}, \mathrm{Nb}, \mathrm{Fe}, \mathrm{Ti}$ ) could be retained while metallic tin was produced.

Temperatures attained in the smelting process seem to have been above $1200^{\circ} \mathrm{C}$, likely in the order of $1300^{\circ} \mathrm{C}$, given the decomposition of columbite group minerals that have higher decomposition temperatures than cassiterite. The analysis of the ceramic fragments, which appear to have been part of some smelting structure, do also suggest that temperatures higher than $1100{ }^{\circ} \mathrm{C}$ were attained at the centre of the charge (walls and bottom of smelting structures are exposed to lower temperatures than the centre of the charge).

The position of the site at a relatively low height and near a stream bend, together with the finding of a cassiterite cache between the site and the stream, can suggest that alluvial cassiterite could have been exploited contiguous to the site. The Ribeira das Lameiras stream contains large rocks that naturally trap sediments, allowing accumulating and renewing of deposits containing cassiterite. Also, the cassiterite samples that provided (by their own) the most similar chemical composition to the slags were the mixture of cassiterite grains panned from Ribeira das Lameiras.

Nevertheless, the tin production in Carvalhelhos could have relied on a mixture of cassiterite sources (that could include very pure cassiterite and associated columbite group minerals) instead of a single source of cassiterite (with Ta and $\mathrm{Nb}$ ). Both primary and secondary sources could have been exploited and used for tin production since there are numerous areas in the Carvalhelhos immediacy with an easy extraction of both types. The recognition of cassiterite from various origins and its differentiation from other dark coloured mineralisations, such as wolframite, could be made by testing of the physical and pyrometallurgical properties of the minerals.

The present work shows that at least for the Iberian Peninsula, cassiterite concentrates with relatively high $\mathrm{Ta}$ and $\mathrm{Nb}$ contents were available and used since a late period in the Iron Age. Some 

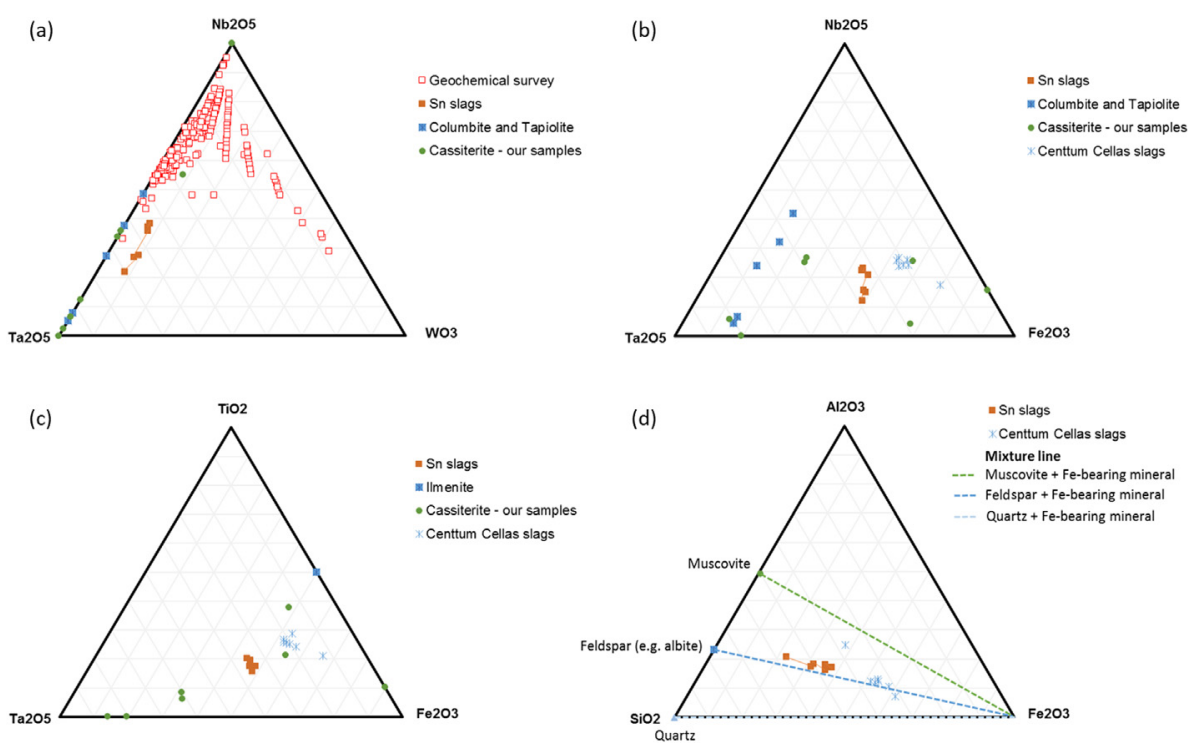

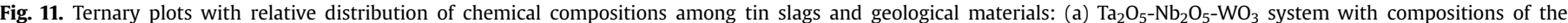

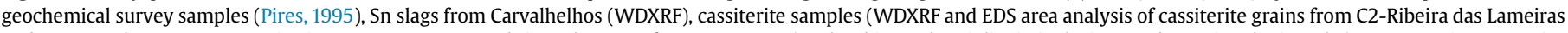

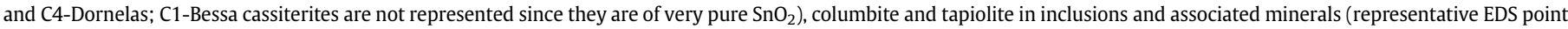

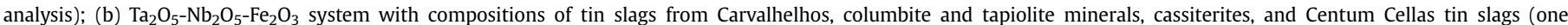

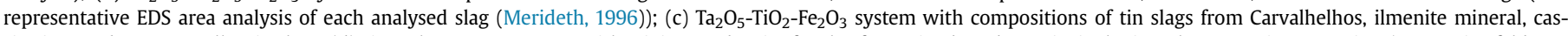

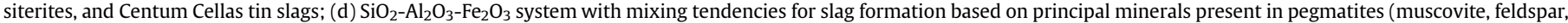
quartz) and Fe-bearing minerals (represented by $\mathrm{Fe}_{2} \mathrm{O}_{3}$ ). Compositions of the Sn slags from Carvalhelhos and Centum Cellas are depicted.

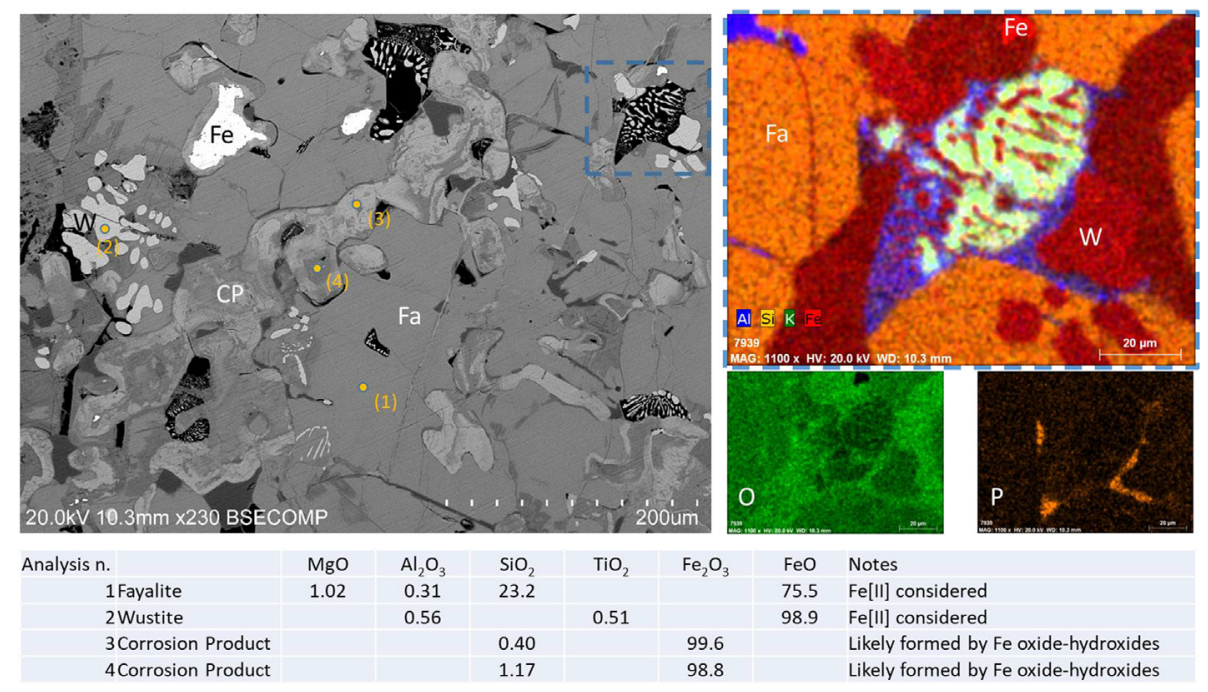

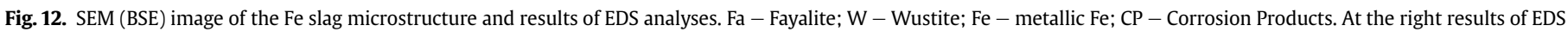
elemental mappings of a eutectic structure composed by a discontinuous phase of wustite surrounded by different phases (such as Al-rich or Si-K-rich).

questions can be raised about the selection and use of different types of cassiterite at different regions and periods, with implications in the development of metallurgical extraction technologies/ skills (e.g. if specific temperature or reduction conditions were needed to reduce ores with different impurities, or improve recovery rates).

Recent smelting experiments made by some of the authors (Figueiredo et al., 2017) to produce tin using two sources of NW Iberia cassiterite (one of the sources was C5, Gondiães, $13 \mathrm{~km} \mathrm{SW}$ of Carvalhelhos) by open and small size fire structures resulted in a very high Sn loss due to volatilisation (up to 80\%). And despite the use of cassiterite ores with $\mathrm{Ta}$ and $\mathrm{Nb}$ the composition and microstructure of the resulting slags were rather different from the
Carvalhelhos slags. Generally, the experimental slags showed much lower $\mathrm{Sn}$, Ta and $\mathrm{Nb}$ contents than the Carvalhelhos slags, with absence of the Ta-rich phase in the microstructure. Only a small number of slags with brown or yellow colour (named type 3) showed a higher $\mathrm{Sn}$ content, but $\mathrm{Ta}$ and $\mathrm{Nb}$ were still in relatively low amounts $(<3 \%)$. The $\mathrm{Ta} / \mathrm{Nb}$ oxide ratio from ores to slags was either kept or showed a tendency for a relative loss of $\mathrm{Nb}$ with respect to Ta, allowing some inter-comparison between ores and slags. Although further experiments should be made, so far it can be suggested that the retention of $\mathrm{Sn}$, Ta and $\mathrm{Nb}$ in slags should be favoured by closed smelting structures and/or by incomplete reactions, minimising losses by volatilisation. Very high $\mathrm{Ta}$ and $\mathrm{Nb}$ contents in the slag would result from a better extraction of Sn to 

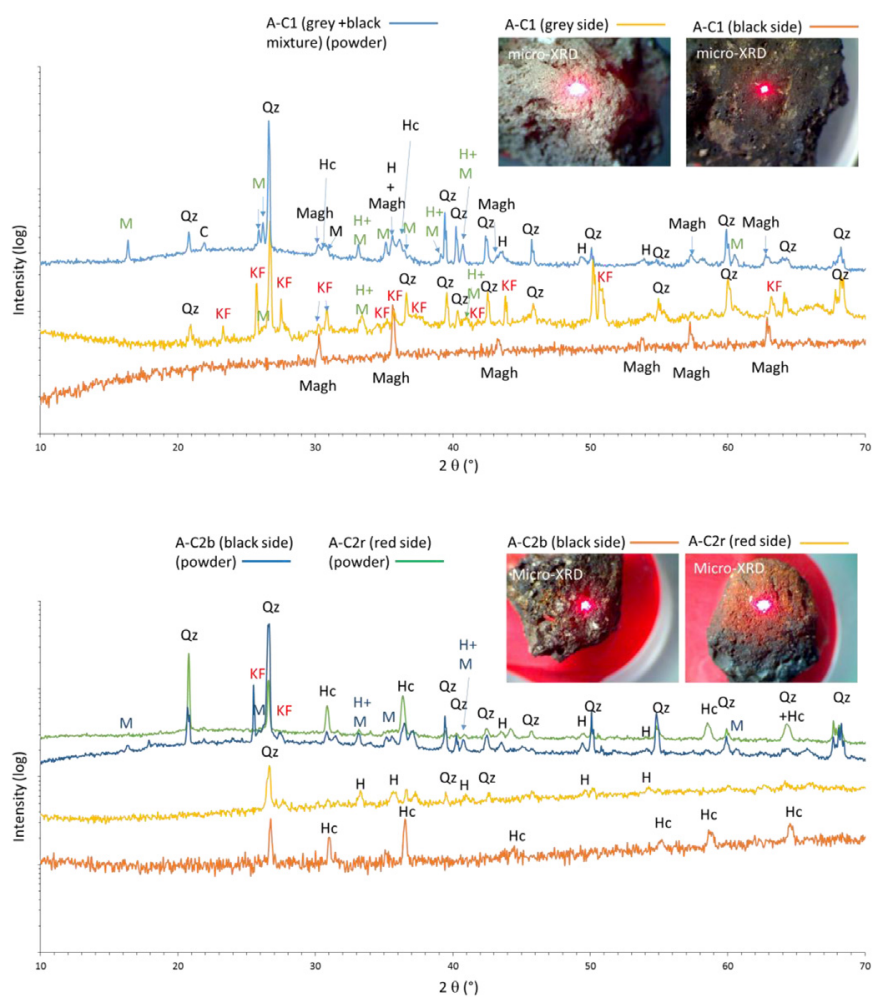

Fig. 13. Powder and micro-XRD diffractograms of the ceramic fragments. Qz - Quartz; M - Mullite; Hc - Hercynite; H - Hematite; Magh - Maghmite; C - Cristobalite; KF- K Feldspar.

metal than the one obtained in the experiments, or the use of ore concentrates with much higher $\mathrm{Ta}$ and $\mathrm{Nb}$ contents than those used.

At least for the Iberian Peninsula, relationship among the $\mathrm{Nb}$ and Ta contents (or other elements such as $\mathrm{W}$ and $\mathrm{Ti}$ ) in slags and original ores could be further investigated. Although not providing a straight answer to provenance issues, such studies in some cases could point to the use of some specific source of cassiterite ore in respect to another, especially in regions were differences in the chemistry of ores are significant. And regarding bronze production in Pre-Roman times, where vast discussion has been raised on the basis of slags with $\mathrm{Sn}$ and $\mathrm{Cu}$ species (Rovira, 2007; Rovira et al., 2009; Figueiredo et al., 2010; Valério et al., 2013), the search for the presence of $\mathrm{Nb}$ and $\mathrm{Ta}$ (as well as $\mathrm{W}$ and $\mathrm{Ti}$ ) in slags could provide indirect information about the use of cassiterite instead of metallic tin for bronze production. In other words, the idea of trade of cassiterite instead of metallic tin and its direct use in smelting operations for bronze production could be reinforced if a combination of some of these elements would be present in slag; on the contrary, the absence of these elements would point out to the use of metallic tin or to the use of relatively pure cassiterite (which also does exist in NW Iberia). The detection and discussion of these elements has only been made recently in the work of Renzi and Rovira Llorens (2016), dealing with the Phoenician metallurgical vessels from La Fonteta (Alicante, Eastern Spain). In some vessels $\mathrm{Nb}$ and $\mathrm{Ta}$ was detected indicating the use of cassiterite in a cementation process for bronze production. Given the absence of mineral deposits in the site's surroundings, this finding could be interpreted as an evidence for the exploitation and integration of the Iberian Hercynian Massif cassiterite deposits in a wide commercial network during Phoenician colonisation.

\section{Conclusions}

The present study has shown new results regarding the presence of tin slags at the Carvalhelhos hillfort, that was occupied from Late Iron Age to Early Roman period (2nd century BCE-1st century $\mathrm{CE}$ ). It has now been demonstrated that metallic tin was produced at the site.

The studied slags have relatively high $\mathrm{Ta}$ and $\mathrm{Nb}$ contents, only comparable to the Centum Cellas slags (central Portugal) and very different from other Western European ancient tin slags. This shows that cassiterite with relatively high $\mathrm{Ta}$ and $\mathrm{Nb}$ contents in solid solution, and/or a combination of pure cassiterite with columbite group minerals (present as inclusions or as associated minerals) were used. These types of cassiterite concentrate would be easily available in the Carvalhelhos region, as well as in many other regions of the NW Iberian Peninsula. Given the geological and morphological characteristics of the region, it seems possible that both secondary and primary sources could have been exploited since ancient times.

The tin slags show a microstructure mostly composed of dendrites of a Ta-rich phase, with occasional presence of a secondary Fe-rich phase, and a dispersion of small metallic Sn globules within a silica-alumina-tin-rich glassy matrix. The microstructure of the slags suggests total fusion of the smelt, with the exception of the most Ta-rich minerals (as tapiolite) and some associated zircon inclusions that were only partially decomposed. The microstructure of the slags suggest smelting temperatures in the order of $1300^{\circ} \mathrm{C}$.

The study showed that some ceramic fragments from the site could be part of a smelting structure. Two samples studied indicate the use of non-calcareous clays, with moderate refractory properties (judged by modern standards). The formation of cristobalite and mullite suggests that the fragments were subjected to temperatures over $1100^{\circ} \mathrm{C}$, which are in agreement with a $100-300^{\circ} \mathrm{C}$ higher temperature at the centre of the charge, corresponding to the temperature of the slag formation. The identification of hercynite and maghemite shows that the fragments were exposed to reducing atmospheres, as expected if they were in contact with a smelting operation.

An iron slag was studied that showed absence of tin traces. This slag suggests that the local habitants were also involved in iron metallurgy.

In conclusion, the present study indicates that the Iberian indigenous communities were exploiting their local tin resources for production of tin metal, at least since the Late Iron Age-Roman transition, with smelting operations performed inside settlements. Future studies of the site and of metallurgical vestiges from other Iberian hillforts may provide further evidences on Iberian tin production extension and intensity in ancient times.

\section{Acknowledgements}

This research was financed by the Portuguese Science Foundation (FCT-MCTES) through the grants SFRH/BPD/97360/2013 and SFRH/BD/65143/2009 to EF and JF, and through the Projects UID/ CTM/500025/2013 to CENIMAT/I3N, UID/Multi/04449/2013 to Hercules Lab and PEst-OE/CTE/UI0039/2014 to ICT. The anonymous reviewers are kindly acknowledged for their detailed and helpful comments and suggestions.

\section{References}

Arruda, A.M., 2009. Phoenician colonization on the Atlantic coast of the Iberian Peninsula. In: Dietler, M., López-Ruiz, C. (Eds.), Colonial Encounters in Ancient Iberia, Phoenician, Greek, and Indigenous Relations. University of Chicago Press, 
pp. $113-130$.

Beagrie, N., 1985. Some early tin ingots, ores and slags from Western Europe. Hist, Metall. 19, 162-168.

Comendador Rey, B., Reboreda Morillo, S., Kockelmann, W., Macdonald, M., Bell, T., Pantos, M., 2008. Early bronze technology at Land's end. In: Western Iberia, North, Paipetis, S.A. (Eds.), Science and Technology in Homeric Epics. Springer Science + Business Media B.V, pp. 113-131.

Charoy, B., Lhote, F., Dusausoy, Y., Noronha, F., 1992. The crystal chemistry of spodumene in some granitic aplite-pegmatite of Northern Portugal. Can. Mineral. 30, 639-651.

Chirikure, S., Heimann, R.B., Killick, D., 2010. The technology of tin smelting in the Rooiberg Valley, Limpopo Province, South Africa, ca. 1650-1850 CE. J. Archaeol. Sci. 37, 1656-1669.

Chumarev, V.M., Par'evich, V.P., Mansurova, A.N., Kozhakhmeto, S.M., 2008. Phase transformation and the kinetics of metal reduction during the interaction of columbite, tantalite, and wodginite with carbon. Russ. Metall. 2, 99-103.

Debroy, T., Patankar, A., Simkovich, G., 1990. Fuming of stanous oxide from silicate melts. Metall. Trans. B 21B, 449-454.

Duval, D.J., Risbud, S.H., Shackelford, J.F., 2008. Chapter 2 - mullite. In: Shackelford, J.F., Doremus, R.H. (Eds.), Ceramic and Glass Materials: Structure, Properties and Processing. Springer, pp. 27-39, 2008.

El Ouahabi, M., Daoudi, L., Hatert, F., Fagel, N., 2015. Modified mineral phases during clay ceramic firing. Clay Clay Miner. 63, 404-413.

Fernandes, C.M.B., 2008. As Minas de Ervedosa (1906-1969): Efígie de memória e narrativa. Master Thesis. Universidade Autónoma de Lisboa.

Ferreira, N.M.R., Noronha, F., 1987. Prospecção de estanho em áreas envolventes dos maciços graníticos das serras do Gerês, Barroso e Cabreira. Actas da IX Reunião sobre a geologia do Oeste Peninsular, Porto. Mem. Mus. Labor. Miner. Geol., Fac. Ciências do Porto 1, 433-449.

Figueiredo, E., Lackinger, A., Comendador Rey, B., Silva, R.J.C., Veiga, J.P., Mirão, J., 2017. An experimental approach for smelting tin ores from Northwestern Iberia. Mater. Manuf. Process. 32 (7-8), 765-774.

Figueiredo, E., Silva, R.J.C., Senna-Martinez, J.C., Araújo, M.F., Fernandes, F.M.B., Inês Vaz, J.L., 2010. Smelting and recycling evidences from the late bronze Age habitat site of Baiões (Viseu, Portugal). J. Archaeol. Sci. 37, 1623-1634.

Freestone, I.C., Tite, M.S., 1986. Refractories in the ancient and preindustrial World. In: Kingery, W.D., Lense, E. (Eds.), High-technology Ceramics, Past, Present and Future. The American Ceramic Society, USA.

Friede, H.M., Hejja, A.A., Koursaris, A., 1982. Archaeo-metallurgical studies of iron smelting slags from prehistoric sites in Southern Africa. J. S. Afr. Inst. Min. Metall 82, 38-48.

Fonte, J., 2015. Paisagens em mudança na transição entre a Idade do Ferro e a época Romana no Alto Tâmega e Cávado. Universidade de Santiago de Compostela. PhD thesis. Available online at: http://hdl.handle.net/10347/13786.

Izoret, L., Marnier, G., Dusausoy, Y., 1985. Caracterisation cristallochimique de la cassitérite des gisements d'étain et de tungstène de Galice, Espagne. Can. Mineral. 23, 221-231.

Jordá Pardo, J.F., Rey Castiñeira, J., Picón Platas, I., Abad Vidal, E., Marín Suárez, C., 2014. Radiocarbon and chronology of the iron Age hillforts of Northwestern Iberia. In: Karl, R., Leskovar, J. (Eds.), Interpretierte Eisenzeiten. Fallstudien, Methoden, Theorie. Tagungsbeiträge der 3 Linzer Gespräche zur interpretativen Eisenzeitarchäologie. Oberösterreichen Landmuseum (Studien zur Kulturgeschichte von Oberösterreich), Linz, pp. 2281-2298.

Kaiser, A., Lobert, M., Telle, R., 2008. Thermal stability of zircon $\left(\mathrm{ZrSiO}_{4}\right)$. J. Eur. Ceram. Soc. 28, 2199-2211.

Kapper, K.L., Anesin, D., Donadini, F., Angelucci, D.E., Cavulli, F., Pedrotti, A., Hirt, A.M., 2014. Linking site formation processes to magnetic properties. Rockand archaeomagnetic analysis of the combustion levels at Riparo Gaban (Italy). J. Archaeol. Sci. 41, 836-855.

Mahé-Le Carlier, C., Lulzac, Y., Giot, P.-R., 2001. Étude des déchets de reduction provenant de deux sites d'exploitation d'étain armoricain de l'Age du Bronze et du Moyen Age. Rev. Archéol. l'Ouest 18, 45-56.

Maia e Costa, H., 1966. Nota sobre as escórias encontradas no Castro de Carvalhelhos. Trabalhos de Antropologia e Etnografia 20, 173-180.

Malham, A., 2010. The Classification and Interpretation of Tin Smelting Remains from South West England. PhD thesis. University of Bradford.

Martins, T., Lima, A., 2011. Pegmatites from Barroso-Alvão, Northern Portugal: anatomy, mineralogy and mineral geochemistry. Cadernos do Laboratorio Xeolóxico de Laxe 36, 177-206.

Martins, T., Lima, A., Simmons, W.B., Falster, A.U., Noronha, F., 2011. Geochemical fractionation of Nb-Ta oxides in Li-bearing pegmatities from the Barroso-Alvão pegmatite field, Northern Portugal. Can. Mineral. 49, 777-791.

Merideth, C., 1996. An Archaeometallurgical Survey for Ancient Tin Mines and Smelting Sites in Spain and Portugal within the Mid-Central Western Iberian Geographical Region 1990-1995. PhD Thesis. University of London.

Meunier, E., 2011. L'exploitation de l'étain dans le Nord-Ouest ibérique entre l'Age du Bronze et la fin de l'Empire romain: bilan et perspectives. Master Thesis. University of Toulouse.

Monna, F., Camizuli, E., Nedjai, R., Cattin, F., Petit, C., Guillaument, J.-P., JouffroyBapicot, I., Bohard, B., Chateau, C., Alibert, P., 2014. Tracking archaeological and historical mines using mineral prospectivity mapping. J. Archaeol. Sci. 49, 57-69.

Murciego, A., Alvarez-Ayuso, E., Pellitero, E., Rodríguez, M.A., García-Sanchez, A. Tamayo, A., Rubio, J., Rubin, J., 2011. Study of arsenopyrite weathering products in mine wastes from abandoned tungsten and tin exploitations. J. Hazard Mater 186, 590-601.

Murciego, A., Garcia Sanchez, A., Dusausoy, Y., Martin Pozas, J.M., Ruck, R., 1997 Geochemistry and EPR of cassiterites from the Iberian hercynian Massif. Mineral. Mag. 61, 357-365.

Neiva, A.M.R., 1996. Geochemistry of cassiterite and its inclusions and exsolution products from tin and tungsten deposits in Portugal. Can. Mineral. 34, 745-768.

Pires, M., 1995. Prospeccão de Jazidas Litiníferas e de minerais associados entre as serras de Barroso e Alvão - Riberia de Pena. Instituto Geológico e Mineiro, Lisboa, p. 57 (unpublished report).

Pliny, the Elder, 1938. Historia Naturalis, book XXXIV. In: Rackham, H. (Ed.), Pliny: Natutral History. Loeb Classical Library. Available online at: https://www loebclassics.com/view/pliny_elder-natural_history/1938/pb_LCL394.241.xml.

Renzi, M., Rovira Llorens, S., 2016. Metallurgical vessels from the Phoenician site of La Fonteta (Alicante, Spain): a typological and analytical study. In: Körlin, G. Prange, M., Stöllner, T., Yalçin, Ü. (Eds.), From Bright Ores to Shiny Metals. Verlag Marie Leidorf GmbH, Bochum, pp. 143-166.

Raghavan, V., 2010. Fe-Sn-W (Iron-Tin-Tungsten), in: phase II - phase diagram evaluations (ASM International). J. Phase Equilibria Diffusion 31, 190.

Rodríguez Díaz, A., Pavón Soldevila, I., Duque Espino, D.M., León Iglesias, M.P., Hunt Ortiz, M.A., Merideth, C., 2013. La explotación tartésica de la casiterita entre los ríos Tajo y Guadiana: San Cristóbal de Logrosán (Cáceres). Trab. Prehist. 70, 95-113.

Rovira, S., 2007. La producción de bronces en la Prehistoria. In: Marimon, J., Silva, J., Grabulosa, P., Cara, T. (Eds.), Avances en Arqueometría. Universitat de Girona I Futur, Girona, pp. 21-35.

Rovira, S., Montero-Ruiz, I., Renzi, M., 2009. Experimental Co-smelting to copper-tin alloys. In: Kienlin, T.L., Roberts, B. (Eds.), Metals and Society - Studies in Honour of Barbara S. Ottaway. Verlag Dr. Rudolf Habelt GMBH, Bonn, pp. 407-414.

Santos Júnior, J.R. dos, 1984. 30 anos de escavações no Castro de Carvalhelhos (Boticas - Vila Real). Rev. Guimaraes 94, 411-424.

Selskiene, A., 2007. Examination of smelting and smithing slags formed in bloomer iron-making process. Chemija 18, 22-28.

Senna-Martínez, J.C., 2011. La conexión lusitana: contactos orientalizantes y búsqueda de estaño y oro en el centro-norte portugués. In: Domínguez Pérez, J.C. (Ed.), Gadir y el Círculo del Estrecho revisados. Servicio de Publicaciones Universidad, Cádiz, pp. 271-279.

Serneels, V., Perret, S., 2003. Quantification of smithing activities based on the investigation of slag and other material remains. In: Proceedings of Archaeometallurgy in Europe, vol. 1. Associazione Italiana di Metallurgia, pp. 469-487.

Soulignac, R., 2017. Les scories de forge du Pays dogon (Mali). PhD thesis. Librum Publishers \& Editors, Hochwald/Basel, Switzerland.

Teixeira, C., 1974. Notícia explicativa da folha 6-B Chaves. Serviços Geológicos de Portugal, Lisboa.

Terry, B.S., Azubike, D.C., Chrysanthou, A., 1994. Reduction/carborisation of columbite concentrate. Scand. J. Metall. 23, 130-136.

Trindade, M.J., Dias, M.I., Coroado, J., Rocha, F., 2010. Firing tests on clay-rich raw materials from the Algarve basin (Southern Portugal): study of mineral transformations with temperature. Clay Clay Miner. 58, 188-204.

Tylecote, R.F., Photos, E., Earl, B., 1989. The composition of tin slags from the southwest of England. World Archaeol. 20, 434-445.

Valério, P., Monge Soares, A.M., Silva, R.J.C., Araújo, M.F., Rebelo, P., Neto, N., Santos, R., Fontes, T., 2013. Bronze production in southwestern Iberian Peninsula: the late bronze Age metallurgical workshop from entre águas 5 (Portugal). J. Archaeol. Sci. 40, 439-451.

Veiga Ferreira, O., Castro, L.A., 1949. Notícia sobre um pilão de minérios Préhistórico. Estudos, notas e trabalhos do Servico de Fomento Mineiro 5, 44-48.

Vilaça, R., 2006. Iron artefacts in contexts of the late bronze Age in the Portuguese territory. Complutum 17, 81-101.

Vilaça, R., Bottaini, C., Carvalho, P.S., Paternoster, G., 2014. O punhal de São Martinho de Orgens (Viseu) no seu contexto local: o ser e o estar. Revista Portuguesa de Arqueologia 17, 127-140.

Wachsmann, S., Dunn, R.K., Hale, J.R., Hohlfelder, R.L., Conyers, L.B., Ernenwein, E.G., Sheets, P., Blot, M.L.P. Castro, F. Davis, D., 2009. The Paleo-Environmenta contexts of three possible Phoenician ancorages in Portugal. Int. J. Naut. Archaeol. 38, 221-253.

Wise, M.A., Cernŷ, P., 1996. The crystal chemistry of the Tapiolites series. Can. Mineral. 34, 631-647. 